Illinois State University

ISU ReD: Research and eData

Theses and Dissertations

9-6-2017

\title{
How Low Can Transparency Go? Secrecy in the Iran-Contra Affair as an Effect of Power
}

Taryn Butler

Illinois State University, tabut11@ilstu.edu

Follow this and additional works at: https://ir.library.illinoisstate.edu/etd

Part of the Political Science Commons

\section{Recommended Citation}

Butler, Taryn, "How Low Can Transparency Go? Secrecy in the Iran-Contra Affair as an Effect of Power" (2017). Theses and Dissertations. 799.

https://ir.library.illinoisstate.edu/etd/799

This Thesis is brought to you for free and open access by ISU ReD: Research and eData. It has been accepted for inclusion in Theses and Dissertations by an authorized administrator of ISU ReD: Research and eData. For more information, please contact ISUReD@ilstu.edu. 


\title{
HOW LOW CAN TRANSPARENCY GO? \\ SECRECY IN THE IRAN-CONTRA \\ AFFAIR AS AN EFFECT \\ OF POWER
}

\author{
Taryn Butler
}

72 Pages

The Iran-Contra Affair is subjected to hermeneutical discourse analysis to uncover, examine, and question the formation of secrecy as an effect of power in democratic society.

KEYWORDS: Iran-Contra, Secrecy, Transparency, Hermeneutics 
HOW LOW CAN TRANSPARENCY GO?

SECRECY IN THE IRAN-CONTRA

AFFAIR AS AN EFFECT

OF POWER

TARYN BUTLER

A Thesis Submitted in Partial Fulfillment of the Requirements

for the Degree of

MASTER OF SCIENCE

Department of Politics and Government

ILLINOIS STATE UNIVERSITY

2017 
(C) 2017 Taryn Butler 


\section{HOW LOW CAN TRANSPARENCY GO? \\ SECRECY IN THE IRAN-CONTRA \\ AFFAIR AS AN EFFECT \\ OF POWER}

TARYN BUTLER

COMMITTEE MEMBERS:

Carlos Parodi, Chair

Nancy Lind

Sherri Replogle 


\section{ACKNOWLEDGMENTS}

This thesis is the product of countless hours of work, and would not have been possible without the help of supportive friends, family, and professors. I would like to thank my family for always believing that I could put together a meaningful piece of work, regardless of how long it took. Thank you to my fellow graduate students that became close friends and were always willing to listen to and critique my ideas. Thank you to my committee members for providing much needed feedback to push my work to its fullest potential. And lastly, I would like to especially thank the Chair of my committee, Dr. Carlos Parodi, for going above and beyond to be accessible every time I had concerns, always supporting my vision, and providing guidance throughout this process.

T. B. 


\section{CONTENTS}

Page

ACKNOWLEDGMENTS

$\begin{array}{ll}\text { CONTENTS } & \text { ii }\end{array}$

CHAPTER I: TRANSPARENCY AND SECRECY AS EFFECTS OF POWER 1

CHAPTER II: REVIEW OF THE LITERATURE AND HERMENEUTICS 3

Secrecy and Transparency in Democracy $\quad 3$

Secrecy Justified $\quad 3$

$\begin{array}{ll}\text { Challenging Cultures of Secrecy } & 6\end{array}$

$\begin{array}{ll}\text { Transparency as a Value } & 8\end{array}$

$\begin{array}{ll}\text { Hermeneutical Analysis } & 12\end{array}$

CHAPTER III: DESCRIPTION OF SOURCES 19

$\begin{array}{ll}\text { Perspectives on Iran-Contra } & 19\end{array}$

$\begin{array}{ll}\text { Administration Officials } & 20\end{array}$

$\begin{array}{ll}\text { Congress } & 20\end{array}$

$\begin{array}{ll}\text { The Public } & 21\end{array}$

CHAPTER IV: EXPLANATION OF THE CASE 24

$\begin{array}{ll}\text { The Iran-Contra Affair } & 24\end{array}$

CHAPTER V: ANALYSIS

$\begin{array}{ll}\text { The Operational Years } & 32\end{array}$

$\begin{array}{ll}\text { Public Fallout } & 45\end{array}$

$\begin{array}{ll}\text { Investigations } & 48\end{array}$

Investigations Come to a Close $\quad 57$ 
REFERENCES 


\section{CHAPTER I: TRANSPARENCY AND SECRECY AS EFFECTS OF POWER}

Transparency is one of the most fundamental principles in a democratic society. The public has the power to hold government accountable through the discussion and debate of policy and action. But, there are also instances in which government has deemed it necessary to keep the average citizen in the dark, typically citing concerns over national security. While it is accepted by most that some things must be kept secret for our own and others' protection, the result is a public narrative that attempts to balance the need to keep national security secrets with public accountability. What determines the space of transparency and the space of secrecy?

How are the space of secrecy and the space of transparency carved out in practice? One case study will guide the focus of the research: the Iran-Contra Affair. This case offers abundant material for understanding how secrecy and transparency are produced in American governmental organizations. It took place within the historical context of the Cold War, and involved the Executive branch along with several federal government organizations. The interpretation of various texts related to the case will show the struggle to expand the space of secrecy against the forces that want to expand the space of transparency. This thesis seeks to uncover and question some of the accepted facts or truths of government secrecy and transparency that developed in the Iran-Contra Affair. In doing so, I will conduct an inquiry into the existing state of affairs regarding practices of secrecy and transparency within the United States Executive Branch. The Iran-Contra story depicts an extensive cover-up campaign to erase events from history and from the minds of the public. It provides an example of how power resources are deployed to produce silence and forgetfulness.

This thesis will first cover relevant arguments regarding the relationship between transparency, secrecy, and democracy and then provide an explanation of hermeneutical analysis. 
Chapter III offers readers an explanation of the sources used to depict the events of Iran-Contra, followed by Chapter IV which describes the events of the affair. Chapter V brings forth the testimonies, notes, and other texts from the Iran-Contra investigations to analyze the manifestation of secrecy as an effect of power using hermeneutical analysis. The goal of the work done here is to dispel some of the "myths" that have become "obvious truths" in U.S. democratic society and not allow the Iran-Contra Affair to remain forgotten in the public consciousness. This thesis will show the forces at work that explain this oscillating gray area between government secrecy and transparency and its effects on democratic society. 


\section{CHAPTER II: REVIEW OF THE LITERATURE AND HERMENEUTICS}

The available literature on the relationship between secrecy and transparency in democracies typically discusses the tensions between the two. Those who critique government secrecy claim that it takes away public accountability which is a staple of democracy. Transparency is treated as a coveted value and is strongly encouraged by organizations to better promote citizen participation and access to information ${ }^{1}$.

\section{Secrecy and Transparency in Democracy}

The current debate between secrecy and transparency in democracy focuses primarily on the negative consequences that government secrecy can have on a democratic society. The secrecy referred to in this thesis is not concerning secrets kept amongst citizens, but rather it is the information withheld by government that is kept secret from the people, whether it be policy, covert action, or other programs. The focus of this research remains confined to secrecy and transparency in democratic governments.

\section{Secrecy Justified}

Many see secrecy as an erosion of transparency because it takes away the opportunity for the public to express its views on the actions of government. Work using this rationale will cite theorists such as Habermas to support claims that the public is to hold government accountable for its actions and it cannot do so if it does not know what those actions are ${ }^{2}$. The suppression of information limits the ability to have the rational debate that is characteristic of the traditional notion of the public sphere and is therefore inconsistent with democracy in this way (Hall, 2005). The government keeps more and more secrets claiming to protect the citizens and institutions, encouraging a culture of secrecy where information is classified in the name of national security

\footnotetext{
${ }^{1}$ Freedom House and Transparency International are examples of such organizations.

${ }^{2}$ See Hall (2005).
} 
more often than information is made available (Pines, 2011-2012). How does government secrecy become "common sense" in a context where secrecy is also condemned for its antidemocratic consequences? (Keeping Secrets, 1990)

Ramsay (2000) explains four common reasons for government secrecy ${ }^{3}$. The first is for reasons of state, typically referring to protecting national security. This is the primary justification for the government keeping secrets from its citizens that entails withholding information on foreign policy situations like ongoing negotiations, covert action, or military movements. If the public knew all the details behind foreign policy actions, especially future ones, it has the potential to jeopardize that action ever being successful. An example is the 2011 raid into Pakistan that resulted in the death of Osama bin Laden. Had the U.S. public been made aware of his whereabouts and the military operational plans before the operation took place, news may have traveled to bin Laden himself, giving him a chance to move before the U.S. ever acted, potentially losing him yet again (Colaresi, 2014).

Ramsay's second reason for government secrecy is that secrecy is an inherent element within power and authority. Theoretically, this notion stems from Weber and his characteristics of bureaucracies in which government agencies, as they are bureaucratic, are competing for money and resources. This competition leads those agencies to restrict their flow of information to hold the upper hand to make a stronger case for more money from Congress (Hall, 2005). The practice of constricting the flow of information has been institutionalized in federal agencies, and has created a self-sustaining cycle. This is a more inadvertent reason for secrecy as opposed to a conscious decision, but is still a reason nonetheless and is the third reason that Ramsay deems ‘bureaucratic explanations’ (Ramsay, 2000).

\footnotetext{
${ }^{3}$ Ramsay (2000) as cited by Hall (2005).
} 
The fourth reason given by Ramsay is the most relevant for this thesis and is the need to thwart dissent (Ramsay, 2000). This reason relates to the ability of those in power to control media reporting through the strategic release of information. When information is released, it is done selectively in a way that manipulates public opinion through the monopolization of public discussion (Hall, 2005). Controlling what information the public is privy to at any given time is a means to control the public conversation regarding what is being discussed and what is not. Ramsay draws on Chomsky's propaganda model for this final reason (Ramsay, 2000). Hall (2005) uses Ramsay's reasons to bolster his arguments on the concept of thought control within democracies. In other words, he examines how government can sculpt public opinion through the control of selective release of information and how this affects the authenticity of the public sphere (pp. 190-193).

Ramsay sees government secrecy as more than simply serving the national security interests of the United States. Instead, he sees it as a network of discussions and decisions which fortify the positions of elites in U.S. society (Ramsay, 2000). This interpretation is most closely related to the idea that secrecy is an effect of power itself. Ramsay's perspective applies directly to the methods used in this thesis. The 'discussions and decisions' that help sustain the status of elites manifest themselves in administrative notes, Congressional testimonies, and investigative proceedings of the Iran-Contra Affair. These texts can be subjected to hermeneutical analysis to show how power was exercised to allow President Reagan and others to retain their roles within the executive branch. Public discourse was shaped to solidify the elite power structure through discourses and practices of secrecy and transparency. 


\section{Challenging Cultures of Secrecy}

Many argue that the culture of secrecy is being challenged by whistleblowers in government and recognize a need to reexamine how whistleblowers are received and how government responds to those situations (Pines, 2011-2012) (Johnson, et al., 2014) (Wood \& Wright, 2015). This dynamic is also part of how power produces secrecy. It ties in with Ramsay's earlier bureaucratic explanations for secrecy and the need to thwart dissent. Whistleblowers upset the balance of the strategic release of information and threaten the future ability of agencies to obtain resources and funding after experiencing an information leak. By releasing information that was meant to be kept hidden from the public, whistleblowers jeopardize the current power structure or the positions held by elites. Elites are not able to control the actions of whistleblowers that have taken the release of information into their own hands and have potentially impacted public opinion, perhaps in a negative way that affects the future ability of elites to shape public discourse.

However, whistleblowers only represent a small bright spot in the many types of fights against government secrecy. Their efforts to declassify information and increase citizen access to information are miniscule in relation to not only the practice by government officials to keep that information classified but also in their ability to selectively declassify information, as was described by Ramsay (2000). The executive has no power over information that is not classified, therefore the classification of information becomes more convenient to serve the best interests of the executive. The classification of information is a question of power exercised through the manipulation of information to shape public opinion or "thwart dissent" as described by Ramsay. It is believed these powers allow the government to construct and/or manipulate the public's discussions by choosing which bits of information to release and when to do so, otherwise 
termed as the need to thwart dissent (Ramsay, 2000). The Iran-Contra Affair reflects a unique case in American history in which Congressional investigators attempted to prosecute executive branch officials that conducted illegal foreign policy action and withheld information from Congress. In Iran-Contra, the administration skillfully manipulated the dissemination of information, which kept the larger power structure completely intact.

Conversely, some scholars believe secrets can be beneficial in protecting democracy (Johnson, et al., 2014). Promoting a culture of secrecy reduces the risk of human behavior where the handling of sensitive information is concerned. The average citizen benefits from not bearing the burden of knowing overwhelming amounts of crucial national security information and having to express opinions on that information (Colaresi, 2014). This issue has been deemed the "secrecy dilemma," namely, the costs of transparency outweigh the costs of secrecy in democratic governments when it comes to issues like military vulnerabilities or negotiating positions (Colaresi, 2014). The costs of the public knowing such information, which likely means foreign governments would as well, are far more extensive than the costs of the public never knowing the details in the first place.

This point is relevant to the case study used in this thesis because it requires an assessment of costs and benefits. Were the Reagan administration's calls for silence in the IranContra operations out of fear that public exposure could tip the scales in the Cold War, or that it might result in the failure to recover hostages from Iran? Or, were the calls for secrecy driven by the need to cover-up illegal, even immoral, operations? Though the costs of transparency are high, they are not to be understood as a weakness, but instead should be looked at as a central strength of democracy, according to Colaresi (2014). 
In democracies, "secrecy" is produced in different sites through different discourses: congressional oversight, amendments to the Freedom of Information Act, and new policies to keep the actions of government in check (Keeping Secrets, 1990) (Johnson, et al., 2014). There are tools in place meant to help combat the potential executive abuse of the power to classify information. Those tools come in the form of freedom of information laws, legislative oversight committees, and press protections to shield the media from punishment for chipping away at government secrecy (Colaresi, 2014).

Ultimately though, intelligence agencies in democracies rely on the respect of the public, which is upheld through oversight by Congress, to prevent abuses of power by the executive (Johnson, Spies, 2000). The "production of secrecy" as an effect of power requires heavy lifting. The existing literature on secrecy within democracies focuses primarily on normative arguments for why secrecy should or should not be a part of the daily functions of a democratic government. In this thesis, I would like to examine how secrecy is produced.

\section{Transparency as a Value}

Transparency is determined by whether citizens have the legal right and practical ability to acquire information on government operations as well as access to ways to petition government agencies to get such information. Transparency is something highly valued in democracies as a right. It does not mean citizens actually have a certain amount of information, but that it is their right and capability to get information should it be needed. It is not about knowing government secrets, but having the right to find out those secrets if a good case can be made.

Transparency as a value itself is rooted in the beginnings of democratic governance.

Disenfranchisement with rule by the few gave way to popularity with the concept of rule by the 
many that was facilitated through the sharing of information, or, transparency (Dahl, 1989). Democratic transparency is defined as "the openness of its political processes and the vast amount of economic, political and social information which is public and generally available" (Starr, 1997, p. 156). This implies "openness, communication, and a willingness to be held accountable" (Mudacumura \& Morcol, 2014, p. 43). The importance of such a model is seen in democracy providing an environment in which opposition is encouraged and can realistically challenge the status quo. A relevant example can be seen in the Freedom of Information Act (FOIA) in the United States. This document gives citizens the ability to petition to gain access to specific information if they can make a legitimate case for their right to know. It gives citizens the right to continue to dig for information. However, although FOIA gives the impression of government transparency and easy access to information, the process required to submit a FOIA request is farcical. The bureaucratic processes, piles of paperwork, and requirements for submitting a FOIA request discourage many from ever applying. This shows the current struggles against 'democratic' barriers that put up the front of transparency yet depress the desires of citizens to pursue their quests for information.

Transparency is necessary for democratic society to be knowledgeable, hold government accountable, and provide a safe environment for political opposition (Starr, 1997). The idea of open opposition to policy through the promotion of transparency can allow the executive branch to carefully form or rethink policy, which in turn may help eliminate the number of unfavorable positions or better prepare for future threats (Colaresi, 2014, p. 15). More than simple opposition to policy is typically necessary to induce change, but a policy of transparency is the beginning of such a process to produce a more knowledgeable public. The practical applications of transparency as a value are prevalent in democratic society. 
In The Structural Transformation of the Public Sphere, Jürgen Habermas describes the creation of the public sphere most basically as:

“...a realm of our social life in which something approaching public opinion can be formed. Access is guaranteed to all citizens. A portion of the public sphere comes into being in every conversation in which private individuals assemble to form a public body." (Habermas, 1984, p. 49).

The public sphere is the result of various economic developments, namely people who did not align with the monarchy or the church began gathering to discuss literature and art (Habermas, 1991). The most important aspect of the public sphere was the rational critical debate that would take place when private citizens came together to keep state power in check. In the beginnings of this public sphere, the people's discussions on art evolved into critiques of government that started to affect public opinion which in turn impacted political decisions. The public sphere was a way for citizens to talk about their interests, and provided an acceptable space to criticize the government.

The public sphere underwent many changes throughout history. With the introduction and dominance of capitalism, people became driven by the materialistic consumption of goods and services, leading the public sphere to be devoured by elites. Capitalistic desires overtook citizens' desires to discuss government and policy. Working, accumulating money, and consumerism became the foremost concern of the public. The abandonment of the public sphere by the "public" left an open opportunity for elites to garner more power through their control over this domain by limiting access to information through the declaration of secrecy. Instead of citizens setting the agenda, decisions began to be made by elites and manipulated in such a way that would garner positive public opinion. Categorizing information as "secret" is a powerful way of shaping the public's understanding of everyday events. The public sphere has been taken over by elites and is therefore no longer serving to keep state power in check. 
Habermas believed that open debate was a necessary condition for a democratic society and warned that the disappearance of the public sphere could lead to increased government secrecy (Habermas, 1991). The public sphere is meant to be a space for citizens to discuss views on policy and events, it is not a place for elites (Habermas, 1991). The taking over of the public sphere makes the whole 'public' notion obsolete and there is no longer a pure dialogue taking place amongst everyday people. There is a distinction made between a member of the "public" and an "elite"; elites serve in positions of power, they are the decision-makers whereas the common member of the public does not typically have access to those powers. This being the case, the public sphere is no longer "public", and its disappearance means there is no longer any discussion to influence public opinion, which in turn would influence policy or keep government in check. Without the threat of potentially negative public discussion on action, the government may choose to pursue policies without ever needing to inform the public at all. A central feature of the public sphere is its "necessity of discursive justification of democratic politics" (Benhabib, 1992, p. 119). Without it, government may begin showing signs of authoritarianism, i.e. more government secrecy in this case. The public sphere is the intermediary in what is meant to be a give-and-take relationship between government and the people. It is not a retroactive critique of government action, it is something that takes place during the formation or implementation of policy, or after, in some cases. The public sphere has been replaced by elite private citizens that can conceal information and have closer personal ties with the actions of the state, such as hefty donors to political campaigns or big business executives, for example. Those in positions of power in government can choose what information to share and when to share it. Today, the public has been reduced to a more passive body that is reliant on the selective release of information, or are otherwise forced to accept its denial. 
Habermas' work is relevant because government secrecy erodes the public sphere where the public is no longer able to talk about ideas and hold government accountable for its actions. Government secrecy erodes the public sphere because the executive elite can control the public dialogue by selectively releasing information to the media. Choosing which information to share and which to keep secret is a form of power that is inherently embedded into the executive.

Elites have not completely erased the public sphere, but rather they have perverted or corrupted it. In the Iran-Contra Affair, they did so by instilling forgetfulness into the public's mind which stunted the ability of the public sphere to fulfill its intended purpose. There is a constant battle taking place between the 'public' in the sphere and the elites which seek to control it. It is not entirely erased. The public sphere may be 'terminally ill,' but we may yet find a cure for its sickness. Those in power in government have the ability to make decisions that affect the masses. How does the executive power produce secrecy? The text of the Iran-Contra Affair will be subjected to hermeneutical analysis to examine the narrative of secrecy as an effect of power.

\section{Hermeneutical Analysis}

This thesis undertakes a hermeneutical analysis of the Iran-Contra Affair text to shed some light on how secrecy is produced. The Iran-Contra Affair is seen as a text; made up of various discourses such as congressional testimony, books, newspaper articles, and reports that describe the illegal activities, cover-up efforts, and investigation outcomes that took place. These discourses combine to form the larger narrative of the entire affair, and can be analyzed as a whole "text" through a hermeneutical critical perspective.

A critical political perspective serves to question quiescence with the actions, words, and norms of political life (Shapiro, 1989). Critical theory is a means of questioning those things 
which society has always taken for granted. Secrecy as an effect of power exists because it took a great deal of time and effort to produce, not because it has always been present. In this case, this thesis seeks to question the status quo of government secrecy and transparency in the United States by dissecting these 'obvious truths' that were initially effects of power by subjecting the Iran-Contra Affair to hermeneutical analysis.

Along the way, we will find that many things "taken for granted" have been possible as effects of the power to keep things secret. There is a constant struggle for historical memory. Former President Bush may have thought the "affair" was over when he issued his pardon, but the "public sphere" where hard-headed researchers reside does not want to forget.

The Iran-Contra Affair should be read as a "crime scene." A crime was committed in secret, and in response a massive government campaign was mounted to make the entire affair disappear. I want to "re-open" the Iran-Contra Affair because a crime went unpunished, namely: arms sold to a state sponsor of terrorism, and a "secret" war waged against Nicaragua. A culture of secrecy was created in this affair through the conduct of those involved. A conscious decision was made to not notify Congress, then the minimum acceptable standard of transparency was put forth during Congressional investigations to "help" the public forget it ever happened. President Bush's pardon is an ultimate exercise of the power to erase events from history as if they never happened. This case can serve as a template for how a "culture of secrecy" can develop into an obvious, accepted truth in democracies.

Hall (2005) uses hermeneutical analysis to examine executive orders and other government documents to explore the extent of the classification system in the United States and the role it has in potentially shaping a culture of government secrecy. He examines various texts to determine the nature and scope of government secrecy and investigates both the internal 
effects of secrecy on the flow of information between government agencies and the external effects between the government and citizens (2005). Hall cites Ramsay's reasons for secrecy regarding his discussion on the control of public thought (2005). These reasons foster a culture of silence in government, and leads to the extensive classification of information. Hall takes on a similar topic to the one attempted in this thesis: how the classification (secrecy) of information affects the ability of democratic society to hold government accountable and how it relates to the effects elites have on traditional notions of the 'public sphere' (2005).

Hall treats government documents as "texts," then uses hermeneutics to expose a pattern: a threat, followed by increased secrecy and legislation, then infringement on individual/group civil liberties (2005, p. 1). He discusses two levels to the analysis: first is what the text says at face value; second is asking what those direct statements reveal to the reader about the authors of the documents (p. 40). After undergoing these two steps, Hall makes judgments on what the documents tell us about the ideology and motivation of the authors (p. 40). He discovers the ideologies of the classifiers of information through his analysis, which helps develop understanding of the motivations behind the U.S. classification system (p. 41).

This thesis relies on Hall and Derong to design the steps of the hermeneutical analysis. The first step in applying a hermeneutical analysis to the Iran-Contra Affair text involves identifying the "text" itself. The story of the affair is narrated chronologically in Chapter IV. The story starts with the inauguration of Ronald Reagan as President of the United States and ends with the media breaking the revelation of the affair.

The second step is identifying the "authors." Who were the main authors of the affair? If the "authors" are limited to those responsible for the affair itself, then they are the grand architects of the foreign policy action and the cover-up operations. However, if we broaden the 
view to include actors who participated in the uncovering of the affair, then Congress and the public must also be included as "authors." The main authors of the Iran-Contra Affair, then, are administration officials (President Reagan included), Congress, and the public. While the Sandinistas, the Contras, Iran, Iraq, and Israel played important roles in shaping the events of the affair, I do not necessarily characterize them as "authors." Instead, I would have them cast as characters in the Iran-Contra story. The term "author" implies having some degree of power to shape the situation, and rarely, if ever, did these "characters" ever have control over the events which took place. Following Hall, I will rely on documents to explain the motivations of the authors. However, most importantly, the textual evidence will be analyzed to understand the power relation between the actors and determine the chain of responsibility.

The third step is the analysis of the historical context to better understand the pattern of power relations. The Iran-Contra Affair took place in the context of the Cold War when the United States was trying to recover its hegemonic position by intensifying its military confrontation against Soviet communism. How did this context affect the use of power in the production of secrecy? Throughout many instances of the production of secrecy in the IranContra Affair, the threat of Soviet communism appeared to be the motivating force. Was the threat of communism the explanation for the production of secrecy? This thesis subjects the IranContra Affair to a hermeneutical analysis to discuss this question. Chapter IV will discuss and analyze steps two and three: the "authors" and "context" of the Iran-Contra Affair.

Derong states that the "text" is not the end product in itself, but it is a phase in the process of understanding (2008). The meaning of the text is not pre-given nor independent of the reader. Meaning is constructed by the reader through their comprehension (Derong, 2008). Derong notes three factors in hermeneutical analysis: the theory of the author's original intention, the theory of 
textual meaning, and the theory of meaning understood by the reader (2008). The relationship between all three makes up modern hermeneutics; they are not mutually exclusive, nor are they independent of one another (Derong, 2008).

Applying this perspective to the Iran-Contra Affair means analyzing the language used by Reagan and his administration to explain how secrecy was produced. In the Iran-Contra case, the 'affair' was discovered because of the public sphere (through media reporting). At a certain point, the public sphere was able to uncover the truth about the affair and serve its purpose. However, elite interference in the sphere stunted its ability to further critique the actions of government.

The public sphere has changed in recent years to a place where public opinion is now dictated by elites who have the power to access information as well as to determine the selective release of that information to the public. Open access to information, on the other hand, is giving the public the potential to seize more power and prospectively use that information to challenge government policies. There are many ways of controlling knowledge, and secrecy is one of them. Secrecy is a means of controlling knowledge which is an exercise of power.

Secrecy can be judged by its process, or the way it was done, and for its effects. In terms of process, the production of secrecy may follow a legal path, or it may be produced to cover-up an illegal act. In terms of effects, secrecy can be used to wage a "secret" war in Nicaragua or to protect people against a panic reaction if something is prematurely revealed. These are questions this thesis seeks to answer through a hermeneutical discourse analysis of the Iran-Contra Affair. This research seeks to question why secrecy became the status quo in the Reagan administration. Why was secrecy accepted as an 'obvious truth' by the public after the investigations? Looking at the discourse of the Iran-Contra Affair may provide some answers. 
The production of secrecy and transparency is part of the relationship between the government and the public. The government seeks to shape the public's opinions through the manipulation of information; the public seeks information to influence government. Understanding how and why secrecy and transparency emerged are the crucial first steps in developing better policies for a more well-functioning democratic government with the ability to keep the delicate balance between the two.

Information on government activities is kept secret, and this practice becomes institutionalized through policies of information classification by the executive. Secrecy tranquilizes the public sphere and bars it from serving its intended function of the discussion of political action, therefore making the public unable to exercise public opinion on government. Government secrecy is a discourse as can be seen in what is said and not said in terms of the classification of information (Hall, 2005). Secrecy must be judged in terms of the process through which it was produced. What was the cost/benefit analysis done by the different actors involved during the production of secrecy? Were the costs and benefits of transparency weighed against the costs and benefits of secrecy (Colaresi, 2014)?

A critical political perspective is necessary to examine the potential differences between the actor's justifications for secrecy and the reality of what took place in each case. The justifications refer to the stated reasons for secrecy or for the cover-up of Iran-Contra, such as to save lives or to fight communism. The reality will surface through a hermeneutical analysis of the Iran-Contra Affair. I am passing judgment on the secrecy in this case through the process by which it was created, and by considering its real-life effects compared to its intentions.

Chapter III will offer a description of the sources used for the analysis of the case study. These sources can be broken up into three categories: a) administration officials; b) Congress; 
and c) the public. The data are picked according to its "significance to the overall narrative of the affair", leaving out some of the more minor details or individuals that contributed little to the overall storyline. 


\section{CHAPTER III: DESCRIPTION OF SOURCES}

The Iran-Contra 'case' has been closed for many years. The public accepted the events of the affair and moved on, forgetting the significance of what happened. While it seems that the case is closed, I seek to re-open the case and bring charges against President Reagan for being the motivating source behind the Iran-Contra Affair. Demonstrating his culpability in this case would show the ease with which presidents have been able to exercise their power and influence over their administrations to promote a culture of secrecy.

The affair has been widely studied and there have been multiple variations of how the story is told. Many different readings of the affair offer their own explanations and interpretations as to how and why the events took place. Given the abundance of material to choose from, I thought it necessary to have a note on the sources chosen for this thesis. This chapter serves to discuss some of these different readings and explain the resources I picked for the description and analysis chapters of this case study that follow. As stated previously, there are three main categories which the sources used in this thesis can fall under: administration officials, Congress, and the public. Within each category, there are a variety of perspectives on the Iran-Contra Affair.

\section{Perspectives on Iran-Contra}

While the government tries to erase the Iran-Contra Affair from public memory, books, journal articles, newspapers, etc. have interpreted the Iran-Contra Affair with a variety of perspectives. The entire affair had an incredible amount of publicity and has been thoroughly studied. Sometimes the best thing that can be done is to keep memory alive when any other form of justice is unable to be attained. An initial point worth noting is that Iran-Contra is never 
strictly referred to as a scandal, but rather is called the Iran-Contra "Affair": something meant to be kept secret, the efforts to keep it secret, and the revelation at the end.

\section{Administration Officials}

Key players in the administration such as Richard Secord, Robert McFarlane, Oliver North, and Ronald Reagan all wrote books in the early 1990s following the aftermath of the affair and each is used in this thesis to describe some of the thoughts and interpretations that each of them had regarding the events that took place. There is a lot of "he said, she said" throughout these books, but it offers an interesting perspective of how even after the investigations came to an end and the affair faded into the back of the consciousness of the American people, those central to the operation continued to discuss its occurrence and significance. Richard Secord, for example, wrote Honored and Betrayed in 1992 which responds to the Reagan administration that left him out to dry after playing a central role in the Iran-Contra operations. Secord is obviously critical of the administration's actions. He believed that the arms sales and diversion of funds operations were wrong and illegal, and was never supportive of the operations. In response, Secord was ostracized by his colleagues and run out of the administration for his dissenting opinions.

North's book Under Fire written in 1991 states that Reagan "knew everything" about the events of Iran-Contra, yet this information never came out during the investigations. Many of the sources written in hindsight of the operations are critical of administration officials and attempt to place blame on individuals or the entire administration.

\section{Congress}

Excerpts of congressional testimony from the investigations play a prominent role, providing much of the "text" of the Iran-Contra Affair. Other sources include transcriptions of 
minutes from meetings, notes from official meetings obtained through the investigations (some that were not declassified or uncovered until many years after the investigations). Reports that followed the investigations were not very effective in issuing judgment or punishment, yet they still provide an image of the political outcomes of the affair. Instead of definitively pointing the finger to one or more individuals, reports criticized the lack of management or control Reagan held over his staff, but maintained that he was more of a victim here instead of the culprit.

\section{The Public}

The "public" here describes many individuals or groups that are not part of the government. This includes journalists, academics, and even the average student or citizen that has taken part in critical debate on the Iran-Contra Affair. The "public" provided most of the critical perspectives of the affair. For some, the affair was a blatant misuse of presidential power to pursue personal goals instead of acting in the best interests of the United States (Byrne, 2014). Byrne (2014) offers all the crucial details in both the Nicaragua and Iran operations. Byrne reexamines the affair with the assistance of previously classified documents and materials that give a better view of events that could not be interpreted accurately at the time the affair broke out. These documents are important in the debate about "public memory" or in the controlling of information by elites. Information was classified by officials during the cover-up, but is now available for public viewing. This availability of information is significant in the "struggle for memory" of the Iran-Contra Affair.

Byrne considers what mechanisms made the affair manifest and attempts to uncover patterns of behavior by officials within Reagan's administration, including Reagan himself by quoting administration notes, Congressional testimonies, and interviews he later conducted in doing his research for the book. This book is a thorough hindsight account of what happened 
from the beginning to the end of the affair, which is why this serves as the foremost source for describing the affair in Chapter V.

A second source is a website by Chimene-Weiss, Eppel, Feigenbaum, Motel, and Pangandoyon that contains comprehensive coverage of the Iran-Contra Affair from its beginnings to the conclusion of the investigations. The website is the result of a research project that began in an ethics and public policy course at Brown University. Research was conducted by students, with the supervision of Professor Ross Cheit, and was funded by an Undergraduate Teaching and Research Award from the Taubman Center for Public Policy and American Institutions. A document from this website has an overview of the entire affair, with sections on the institutional history of the NSC and CIA, separate discussions on the Nicaraguan story and Iran story, the public fallout, and the investigations. While it does not have the in-depth detail that Byrne's book offers, it serves as a solid secondary source of information to supplement some of the finer details of the Byrne book. Having originated in an ethics course, this research has a section on residual ethical issues that arose from the affair: lying to Congress, deception by officials, following orders, and resignation versus obedience (Chimene-Weiss, Eppel, Feigenbaum, Motel, \& Pangandoyon).

The "ethical" issues discussed by this website expand on these themes. One of the serious questions raised was how the executive branch could try and investigate the executive branch for wrongdoings. Lessons drawn from Watergate showed that only a truly independent prosecutor, one not subject to dismissal by the President, would be able to ensure accountability. The independent prosecutor from the Iran-Contra Affair, Lawrence Walsh, took heavy criticism from Republicans for conducting a "witch-hunt" of an investigation (Chimene-Weiss, Eppel, Feigenbaum, Motel, \& Pangandoyon). Another issue was the plausible deniability that was 
provided to President Reagan in the design of the Iran-Contra Affair. Was "plausible deniability" characterized by the plausibility that Reagan may not have known about the affair? Or, was it characterized by the lack of a smoking gun to prove Reagan's culpability? Unfortunately, questions like these were never given any consideration during the investigations because of the hangover from Watergate that still lingered over Congress (Chimene-Weiss, Eppel, Feigenbaum, Motel, \& Pangandoyon). The questions raised from these ethical issues are important ones. This website source does not offer answers to these questions, it only identifies them as unresolved issues that emerged from the Iran-Contra investigations. I believe these questions are worth asking, and are ones that were not given enough attention during the affair's fallout. The lack of answers, however, is something that should be resolved.

I review the existing evidence to show that a crime was committed, a cover-up followed, and crimes went unpunished. The impunity in Iran-Contra resulted in the gradual disappearance of the affair from the public eye. This is not the only case of the use of power to erase or distort historical events, but it remains a paradigmatic one. Sometimes keeping memory alive is the best way of achieving justice. 


\section{CHAPTER IV: EXPLANATION OF THE CASE}

The Iran-Contra Affair offers a good representation of the potential negative consequences of government secrecy. Focusing on this case will allow for a better understanding of why certain actions were justified, what went wrong, and how the situation is a representation of what we see today as the status quo of government secrecy. The Iran-Contra Affair of the 1980s took place in the context of the Cold War when the U.S. government adopted a "by any means necessary" mentality to stop the spread of communism and defeat the Soviet Union. This thesis seeks to challenge the fundamental "truths" about secrecy, and applies a "hermeneutical" analysis to the Iran-Contra Affair to show how secrecy, or a culture of silence, was the effect of power.

This chapter is a description of the events of the Iran-Contra Affair as depicted within the chosen sources (explained in Chapter III).

\section{The Iran-Contra Affair}

This is the story of a massive cover-up; an example of how power resources are deployed to produce silence and forgetfulness. This case represents a well-known instance of the production of secrecy and manipulation of transparency in a democracy. It is a story of real events and then efforts to make them disappear or otherwise make people believe they did not happen.

During President Ronald Reagan's second term in office, the administration, the National Security Council (NSC) and the Central Intelligence Agency (CIA) were swept into a scandal known as the Iran-Contra Affair. This was the result of two seemingly unrelated foreign policy issues that intertwined to create a massive international affair: the "secret" war against the Sandinistas and negotiations with Hezbollah to recover kidnapped U.S. citizens. The United 
States was in the midst of the Cold War with the Soviet Union and President Reagan together with the political elite were working under the assumption that anything could be justified in the fight to roll back the Soviet bloc and prevent the spread of communism. There were several internal factors that contributed to the actions surrounding Iran-Contra. Reagan's personal policy for obtaining his goals was to take the most direct path possible, which in this case meant that some legal and political corners were cut in the process (Byrne, 2014). Byrne argues that the driving force behind the entire operation was Reagan himself, who likely had grounds for impeachment, regardless of the other circumstances that played a role (2014).

The official version of the "secret" war against the Sandinista government of Nicaragua is that the U.S. was supporting "freedom fighters" in their struggle against a government that wanted to impose communism by force in Nicaragua with the help of Cuba and the Soviet Union (Chimene-Weiss, Eppel, Feigenbaum, Motel, \& Pangandoyon, n.d.). These "freedom fighters" were called Contras (a Spanish word meaning counter-revolutionary).

The inauguration of Ronald Reagan in 1981 led to Contras support growing into a fullscale operation involving the President, the National Security Council (NSC), and the Central Intelligence Agency (CIA). Reagan signed an order allowing the CIA to offer arms, equipment, and money to the Contras (Chimene-Weiss, Eppel, Feigenbaum, Motel, \& Pangandoyon, n.d.). This policy was premised on Reagan's belief that covert action was the most effective way to place pressure on the Sandinista regime. In the early 1980's, the public and some in Congress believed the ongoing operation was just a way for the U.S. to undermine the Sandinista regime, a democratically elected government. As a response, Representative Edward Boland led a Congressional effort to end support to all Nicaragua efforts, Contras included (Chimene-Weiss, Eppel, Feigenbaum, Motel, \& Pangandoyon, n.d.). Boland and others who passed the resolution 
believed that the United States should not be involved in funding and supporting a group seeking to overthrow a legitimately elected government regime. Congress equated funding and aiding the Contras to directly interfering in the domestic affairs of another state. The Boland Amendment is critical because it challenged the official version describing the Contras as "freedom fighters" and the purpose of Reagan's proxy war to stop Soviet communism. If the Contras were not freedom fighters defending Western civilization against the expansion of Soviet communism, what was the justification for the war and the cover-up? Where does responsibility lie?

The first Boland Amendment "barred the use of funds 'for the purpose of' overthrowing the government of Nicaragua or provoking a war between Nicaragua and Honduras." (ChimeneWeiss, Eppel, Feigenbaum, Motel, \& Pangandoyon, n.d.). This created a problem for the Reagan Administration that had already pledged their commitment to helping the Contras at all costs, even against the wishes of Congress. The solution emerged from a loophole in the Amendment: if the U.S. did not intend to overthrow the Nicaraguan government, they could support the Contras under the guise of humanitarian aid or through the solicitation of funds from private third-party actors or countries (Chimene-Weiss, Eppel, Feigenbaum, Motel, \& Pangandoyon, n.d.). The Boland Amendment, while a symbolic gesture of disapproval from Congress, did very little in affecting the operations in Nicaragua. The loophole exploited by the Reagan administration represents a key mechanism in the production of secrecy. It shows the persistence of the administration to continue pursuing their operations, regardless of legal barriers placed in their way. In the end, the Reagan administration managed to continue fighting its "secret" war under the cover of a legal loophole.

The CIA continued to aid the Contras in multiple operations including air strikes, the destruction of fuel tanks, and the placement of mines in harbors (Chimene-Weiss, Eppel, 
Feigenbaum, Motel, \& Pangandoyon, n.d.). During this time, National Security Advisor Robert McFarlane secured money for the Contras from Saudi Arabia, while Oliver North (a notable figure in the Iran-Contra affair) obtained funds from Taiwan (Chimene-Weiss, Eppel, Feigenbaum, Motel, \& Pangandoyon, n.d.). The Contras support continued unimpeded by the first Boland Amendment. Congress, seeing its ineffectiveness, passed a second Boland Amendment in 1984. This amendment read:

"During fiscal year 1985, no funds available to the Central Intelligence Agency, the Department of Defense, or any other agency or entity of the United States involved in intelligence activities may be obligated or expended for the purpose of which would have the effect of supporting directly or indirectly, military or paramilitary operations in Nicaragua by any nation, group, organization, movement or individual." (ChimeneWeiss, Eppel, Feigenbaum, Motel, \& Pangandoyon, n.d.)

Though Boland II was meant to represent a more thorough crackdown on support to the Contras, there were still loopholes exploited for its continuation. Third party private donors or countries were still allowed to give aid, and a new discovery was the ability to use the NSC since its technical definition as a body excluded them from the Boland II Amendment (ChimeneWeiss, Eppel, Feigenbaum, Motel, \& Pangandoyon, n.d.). At this point, the role of Oliver North became much more profound. North was a Lieutenant Colonel in the U.S. Marine Corps and was serving as deputy-director of the NSC under the Reagan Administration (Biography.com Editors, 2016).

Reagan trusted North and McFarlane to keep the Contras together at all costs (ChimeneWeiss, Eppel, Feigenbaum, Motel, \& Pangandoyon, n.d.). These efforts came in the form of supplying arms, air supply operations via private airstrips in Costa Rica, and intelligence support. Congressional funding was finally given to the Contras under the guise of humanitarian assistance, and the CIA was allowed to provide training and intelligence to the Contras "under 
the condition that it would not be used for future military operations." This condition was obviously nothing more than a formality. North did not find these efforts satisfactory in funding the Contras at the desired level, so means were sought elsewhere. At this stage, the Iranians entered the scheme through their role as buyers of American arms.

The 1979 Iranian Revolution resulted in the severance of ties between Iran and the United States. The U.S. sought to restore relations, but to no avail. The war taking place between Iran and Iraq from 1980 to 1990 led to the U.S. placing an embargo on Iran, after which Hezbollah responded by taking hostages in 1984 in the state of Lebanon (Chimene-Weiss, Eppel, Feigenbaum, Motel, \& Pangandoyon, n.d.). The U.S. wanted hostages released, and Iran wanted weapons. Through a complex and tiresome series of events, North orchestrated the deal of overcharging the Iranians for weapons and using the surplus to fund Contras operations and supplies (Chimene-Weiss, Eppel, Feigenbaum, Motel, \& Pangandoyon, n.d.). This 'diversionary scheme' is what created most of the controversy after news of the affair was made public.

Initially, the deal was facilitated through Israel instead of by the United States directly. To funnel the funds without suspicion, a front company that came to be known as "The Enterprise" was established and a Swiss bank account was created for the deposit of profits from the Iran deals (Chimene-Weiss, Eppel, Feigenbaum, Motel, \& Pangandoyon, n.d.). After some mishaps with the Israeli facilitation, the U.S. government covertly took over.

In January 1986, Reagan signed a Presidential finding (an act similar to an executive order, but is only shared with a select few) that authorized the sale of arms to Iran. The Enterprise, acting as a third party to avoid liability on the part of the U.S., was now able to sell weapons on behalf of the United States (Chimene-Weiss, Eppel, Feigenbaum, Motel, \& Pangandoyon, n.d.). The U.S. overcharged Iran for the weapons and the surplus was dumped into 
the bank account created by the Enterprise to fund the Contras in Nicaragua. This operation continued for some months, with weapons being sold in exchange for very few hostages. The United States was certainly not satisfied with Iran's lack of enthusiastic cooperation, yet Reagan urged for the arrangement to push forward.

In October of 1986, a plane carrying supplies for the Contras entered airspace guarded by Sandinista weaponry and was shot down on sight (Byrne, 2014). The crew continued to deny connection to the U.S. government, but Oliver North knew the problem was bigger than initially expected. He ordered the remaining aircraft and airstrip owned by the Enterprise destroyed to erase any indication of outside government involvement in Contras operations. However, by November, Lebanese newspapers broke the details on the Iran arms deal with the United States, and this leak was soon followed by an uncovering of the connection between the weapons trades and the Contras supply plane operations by linking a passenger on the plane to CIA operations (Chimene-Weiss, Eppel, Feigenbaum, Motel, \& Pangandoyon, n.d.). These events led to an unraveling of the whole affair in the United States.

The U.S. could not openly negotiate with Iran to free hostages, nor could it openly fund what some saw as a terrorist insurgency to overthrow the Sandinistas. However, a way was found to do both using the Enterprise as intermediary. In the fallout after the initial media firestorm of Iran-Contra, mixed messages by the President and other members of the administration created mass confusion which threw presidential credibility in doubt in the public discourse. Reagan had ensured that the greater bureaucracy of the administration, and the CIA, was kept in the dark on the details of this operation (Diamond, 2008) (Richelson, 2016). Information regarding Iran-Contra was highly compartmentalized to avoid intense scrutiny and 
to provide deniability (Byrne, 2014). Many Congressional proceedings resulted from the affair that can offer a thorough investigation of how secrecy came to be the status quo. 


\section{CHAPTER V: ANALYSIS}

A hermeneutical analysis is applied to the Iran-Contra Affair to flesh out and make sense of the production of government secrecy and transparency. The public has accepted 'obvious truths' about secrecy and transparency. We assume that the democratic government of the United States is transparent with its people. We accept without question that some secrets are kept for our own safety and security. Why do we accept these things as true?

This analysis aims to look at how and why secrecy and transparency came to be produced as effects of power in the Iran-Contra Affair to answer the question above of why we simply accept some things as inherently true instead of questioning the status quo.

The Iran-Contra Affair was a complex series of events that revealed a high level of information compartmentalization within the United States federal government. Many players had an integral role in the selling of weapons to raise funds for the Contras, and the public and Congressional fallout can offer an interesting analysis into the mechanisms of power at play that set the stage for the entire affair. In Congressional testimony, press briefings, interviews, etc. that followed the break out of Iran-Contra, we can begin to see commonalities amongst the people who found themselves at the heart of the scandal. Chapter IV provided the first step in the analysis. This chapter uses a critical hermeneutical perspective to look at the historical proceedings chronologically and draw out patterns from within the available texts. It reveals the "authors" of the affair, and brings the historical context into the narrative. It is an investigation of the Iran-Contra Affair as a crime swept under the rug. The investigation is processed using hermeneutics to unearth the underlying foundations in the affair which expose "myths," or assumptions, that guided behavior during and after the affair. 
This thesis seeks to challenge some of the "myths" that have been accepted about the Iran-Contra Affair. One of those myths is that President Reagan was not responsible for the operations that took place during his tenure in office. A second myth concerns the motivations behind the Iran-Contra campaign: the affair was motivated by the need to rescue hostages and stop the spread of communism in Latin America. These myths will come into play throughout this chapter, and the inner workings of them will be unveiled to show that they are indeed false. Ultimately, it questions the "obvious truth" that the U.S. democratic government is transparent with the people. We have come to understand that no government is totally transparent out of necessity to safeguard some secrets in the interests of national security, but this justification seems to have become a blanket response to pacify the public. The ramifications of such a practice are exemplified by the fallout of the Iran-Contra Affair.

\section{The Operational Years}

"I don't want to back down. I don't want to accept defeat," said President Reagan in regards to using covert methods to fund the Contras in their fight against the Sandinistas (U.S. National Security Council minutes, 1981). Reagan wanted forceful, decisive action in aiding the Contras by any means necessary. His assertiveness was seemingly driven by "his vision of the Nicaragua issue being part of the global struggle against communism" (Byrne, 2014). As he later put it: "Based simply on the difference between right and wrong, it was clear that we should help the people of the region fight the bloodthirsty guerillas bent on robbing them of freedom" (Reagan, 1990, pp. 478-479). In referring to the Sandinistas as "bloodthirsty guerillas," there is little doubt that Reagan's demonization of supposed communist agents was a driving force behind his resoluteness for helping the Contras. But how seriously did the Sandinistas threaten U.S. national security? Was the justification of "stopping communism" only that: an excuse to 
interfere in Latin America? Helping Nicaraguans fight bloodthirsty communist guerillas is one of the "myths" of the official version of the Iran-Contra narrative.

President Reagan's resolve solidified stopping the Sandinista regime as a primary policy goal of his administration. However, because overthrowing the Sandinista government was a policy with strong political resistance, the Reagan administration organized its power to implement covert operations and then cover-ups of those covert operations. The Reagan administration, all the way from the President through state agencies and operational agents, was organized to implement a secret policy. Presidential power shaped the policy of secrecy, including the creations of a shield to protect the President from any political backlash. This thesis examines the Iran-Contra Affair to see how secrecy is produced in U.S. democracy.

The fundamental reason for the affair being an "affair" was the illegality, or "scandal" of providing military assistance to a rebel group attempting to oust a democratically elected government. Because of its illegality and immorality, the operation had to be done in secret. Reagan's push to achieve his goal of aiding the Contras clashed with legality, so to continue his policy, the operation had to be kept quiet. In 1983, Reagan signed a memorandum directing the Department of Defense (DoD) to "provide maximum possible assistance to the Director of Central Intelligence for improving support to the Nicaraguan resistance forces" (U.S. Department of Defense, 1983). The order was implemented and the CIA started conducting covert operations in Nicaragua. Oliver North's notes verify this assistance by the U.S. military, along with confirmation that the relationship was never to be reported to Congress (Emerson, 1988, pp. 89-94, 150). Keeping things secret included public denials by the DoD of any connection to the CIA's actions. Covert operations allowed President Reagan to help the Contras without ever having to give specific policy orders, only stating his end goal. Reagan thought he 
was doing the "right" thing (overthrowing communism) and that as such he had license to ignore the law.

Reagan's emotional attachment to the issues had a profound effect at making administration officials push for policies in those areas over others. He was decisive, though it was clear that he was not an "x's and o's" kind of policymaker. He would state his opinions on an issue, then expect his advisors and staff to work out the details to get the job done (Byrne, 2014). The statement of his goals was an expression of his power, and this power forced a culture of secrecy to take hold during Iran-Contra because of the illegality of the campaign. It was Reagan's desire to achieve his broad objectives that drove officials in his administration to act without Congressional authorization to please the President. If the affair were ever to be revealed to Congress or to the public, his administration feared Reagan would be prosecuted not only by the media, but by Congress as well.

An important factor in the production of the affair was certainly the personality of Reagan himself, and the sense of loyalty he was able to instill in officials in his administration. However, important contextual factors need to be considered to explain the ability of the Executive to implement covert operations, such as: the fierce political polarization in Congress, increased tensions from the Cold War, and the "hangover" from the Nixon Watergate scandal of the 1970's. There was an unwillingness of Congress to pursue harsh punishments against the Republican executive after taking such a hard hit in the 1970's when Nixon was forced to resign. The party was in disarray, and was still licking its wounds when Reagan began the secret IranContra campaign that later required a full display of power to keep it secret, even in the face of hard evidence to the contrary. 
President Reagan repeatedly expressed a strong motivation for achieving two policy goals: support for the Contras and rescue the hostages taken by Hezbollah. In an exchange with his then deputy national security advisor John Poindexter, Reagan showed his strong feelings towards rescuing the hostages:

Poindexter: “... We've now agreed that if the hostages are harmed (executed), we will conduct the strikes..."

President (snapping fingers) "Like that.” (Minutes of National Security Planning Group meeting, 1985).

After the first Boland Amendment placed restrictions on the U.S. providing aid to the Contras, Reagan gathered his staff in the Situation Room of the White House to discuss options. Notes from the meeting described Reagan as vocal, as he usually was when the topic was of great personal concern to him. He urged his aides to be "more active" and to "keep the pressure on Nicaragua to make sure that... our friends know they can rely on us" (National Security Planning Group Meeting-- Subject: Central America, 1984). Reagan's use of “our friends” demonstrates how personal it was for him to protect Nicaragua from falling under communist rule. His push for more support was acted upon by his subordinates, without explaining the precise measures that were taken, primarily to shield the President from criticism should Congress ever become wise to the administration's ventures in Central America. Fighting communism in the name of national security would become the final justification, or the final cop out, for breaking the law on the Nicaraguan-side of the affair.

With Boland barring the simplest and easiest routes to aid the Contras, Bill Casey suggested looking to third-party countries to raise money for the rebels (Byrne, 2014). McFarlane began searching for a willing donor and found one in Saudi Arabia. Everyone 
involved lied to Congress, saying that the Contras somehow raised the money themselves. Reagan personally gave an order that no one, other than those already involved, was to know about the Saudi donation (McFarlane, testimony at Oliver North trial, 1989, pp. 4201-4206). Soliciting third-party countries was explicitly prohibited by the Boland Amendment, explaining the 'official' practical reason for secrecy. But, underlying this warning is an important note: it is an example of a blatant call for secrecy that manifested as a direct result of Reagan's power and influence over his administration. President Reagan's power was able to instill silence or secrecy upon administration officials.

Post-Boland I, Oliver North oversaw operations conducted by hired mercenaries and took part in many quid pro quo arrangements that would raise legal questions during the Congressional investigation into Iran-Contra (Byrne, 2014). Boland I did not include the NSC, which gave North the latitude to conduct such operations. However, after the passage of Boland II, there was disagreement on its interpretation of whether the NSC was barred from organizing or performing activities which aided the Contras (Byrne, 2014). This ambiguity led the NSC to conduct its operations through less obvious channels, simply to avoid having to answer to Congress, something that could potentially disrupt the flow of aid. The complex operation of secretly aiding the Contras was largely possible because of the assumption that if Nicaragua was lost to communist influence, it would only be a matter of time before the rest of Latin America followed. This assumption has largely gone unexamined, but it is yet another "myth" of the affair that was used to justify breaking the law.

The Director of Central Intelligence at the time, Bill Casey, developed a close relationship with Oliver North, seeming to take him under his own wing (Byrne, 2014). When North was pulled into the NSC operation, he claimed, “...knew nothing about covert operations," 
but that, "Casey told me what to do" (North, Under Fire: An American Story, 1991, p. 180). The two men upheld similar goals and ideals concerning aid to the Contras rebels. The rapport between North and Casey provided a way for the State Department to maintain less direct involvement while allowing North to take some of the operational strain off the CIA (Byrne, 2014). Casey aided by finding ways around the Boland bans and assisted North in setting up The Enterprise by structuring it in such a way that even the CIA could not scrutinize its activities (Byrne, 2014). Operational efficiency demanded to keep things secret even among executive agencies.

The close relationship shows the conglomerate that formed between the NSC, CIA, and DoD/Department of State. The existence of such an interagency relationship demonstrates how widespread the operation was in the Reagan administration. With all these different players involved in the game, what was the source keeping everything connected? What was the driving factor behind such a largescale operation that managed to somehow maintain its cover for years before being revealed? Although actors such as North, Casey, McFarlane and Poindexter were directly involved in the implementation of Iran-Contra policies, the driving force behind those policies was Ronald Reagan. Reagan's broad policy goals drove members of his administration to carry out his bidding. The President was results-driven and had little penchant for the operational details as long as he did not have to deal with an overly-partisan Congress.

In spring/summer 1985 the covert Iran arms operation received presidential approval, swaying several hesitant Cabinet members by having backing by the Israeli government (Byrne, 2014). Reagan was approached by his Chief of Staff Donald Regan about the Israeli-Iranian proposal of establishing ties with "moderate" Iranian officials to free hostages (Byrne, 2014). As will be analyzed more thoroughly later in this section, the justification of "freeing hostages" did 
not come about through humanitarian motivations of wanting to save lives. This is yet another "myth" of the Iran-Contra Affair. It served only as a justification for breaking the law.

Though the goal stated publicly in the Congressional investigation was to establish this sort of long-term partnership to better the relationship between the U.S. and Iran, for Reagan the most pressing goal was the release of hostages. This point can be seen in a quote from Reagan's book:

"The truth is, once we had information from Israel that we could trust the people in Iran, I didn't have to think thirty seconds about saying yes to their proposal.... I said there was one thing we wanted: The moderate Iranians had to use their influence with the Hizballah and try to get our hostages freed." (Reagan, 1990, p. 506)

The excerpt above from Reagan's autobiography reinforces claims that freeing hostages was one of his pet projects and he was willing to take any avenue that would bring that project to fruition immediately, regardless of political process or legality. Saying that there was "one thing we wanted" shows where the President's priorities were during this time. His desire for releasing hostages stemmed from not wanting to appear weak. Reagan, as a former actor, always valued his reputation and believed that if he was unsuccessful in saving the lives of hostages, it would give him the appearance of being a weak president, incapable of achieving anything. Freeing hostages seems to be something that Congress would generally approve of, so why the need to keep it secret? Because of the means by which this had to be done. Selling arms to a state sponsor of terrorism would have been condemned by Congress, regardless of the supposed underlying motives. Reagan's officials convinced him of this, and he was therefore on board with the operation. However, other members in his administration seemed to have an ulterior motive in selling arms to Iran. It seemed that the individuals involved became more concerned with growing the number in their bank accounts as opposed to saving lives. 
When one of the initial arms deals went awry, many in the administration wanted to discontinue the weapons sales. But, Reagan was a strong advocate for its continuation and therefore the plan persisted (Byrne, 2014). McFarlane stood to lose a lot if the deals went south, and he was reluctant to continue moving forward. His primary impetus for moving forward was the President's immense desire to navigate successfully through the ongoing hostage crisis (Byrne, 2014). McFarlane noted that Reagan was "obviously pleased" when one hostage was released following the initial arms deal (McFarlane \& Smardz, 1994, p. 40). When faced with the subsequent deal, he did not hesitate, fighting off criticism and doubts from advisors. McFarlane was a key component of the conception of the Iran arms deals on the U.S. side, but the operation would have had no teeth or momentum if not for the President (Byrne, 2014). The other side of the coin is that the President's commitment to releasing hostages could be seen by national and foreign players as a weakness that could be exploited for personal and political gains. That the operation blew up in its face is a demonstration that the Reagan administration did not have full control of the operation.

On December $5^{\text {th }}, 1985$, Reagan signed a presidential finding identifying the "Hostage Rescue - Middle East" operation as covering "the provision of assistance by the Central Intelligence Agency to private parties in their attempt to obtain the release of Americans held hostage in the Middle East....As part of these efforts certain foreign materiel and munitions may be provided to the Government of Iran which is taking steps to facilitate the release of American hostages" (Finding Pursuant to Section 662, Scope: Hostage Rescue--Middle East, n.d.). The finding made the arrangement look like an arms-for-hostages deal.

A second legal issue arose from a section in the finding which stated, "Because of the extreme sensitivity of these operations, in the exercise of the President's constitutional 
authorities, I direct the Director of Central Intelligence not to brief the Congress of the United States... until such time as I may direct otherwise" (Finding Pursuant to Section 662, Scope: Hostage Rescue--Middle East, n.d.). Though the document had been drafted for Reagan, not written by him, it still bore his signature. This clause went against law that required Congress be notified of every presidential finding, and investigators saw this provision as an attempt to dodge presidential responsibility (Byrne, 2014). White House officials insisted that protecting the lives of hostages was worthy of such secrecy. Throughout the entire affair, the President and those in his administration worked to justify their actions, especially should the public find out. Despite any rationalizations, the program was still prohibited under the law.

The humanitarian motivation of the Iran side of the Iran-Contra Affair is another "myth." Personal prestige and money were the motives; releasing hostages was a cover-up. Although the President has the authority to go against the law under certain conditions, if saving lives was not the real motive, then President Reagan's authorizations were indeed illegal and wrong.

The U.S. reversed its previous position of preventing arms sales to Iran who they accused of sponsoring terrorist activity. However, the worsening relations between the U.S. and Iran prompted McFarlane to search for means to improve those relations. McFarlane was one of the few actors during the affair that truly held humanitarian motives as opposed to those of greed ${ }^{4}$.

The following quote displays the origins of this potential opening:

"In 1985, Ghorbanifar and Khashoggi came into contact in Hamburg, Germany, and began devising the skeletons of the plan that would eventually become the Iran side of the Iran-Contra Affairs. Three Israelis were drawn into the discussion in the summer of 1985 ... However, from these meetings came the idea to sell U.S. arms to Iran via Israel and the suggestion that to gain the U.S.'s approval for the scheme, American hostages in

\footnotetext{
${ }^{4}$ McFarlane resigned his office before the affair was exposed to the public, citing family issues, but it was well known that McFarlane had encouraged Reagan to discontinue the arms deals towards the end of his time as National Security Advisor. After the affair's exposure, McFarlane attempted suicide due to the shame he felt over his contribution to the embarrassment of Ronald Reagan.
} 
Lebanon could be released." (Chimene-Weiss, Eppel, Feigenbaum, Motel, \& Pangandoyon, n.d.)

Iran wanted weapons to support their ongoing war with Iraq, and they dangled the possibility of opening dialogue with the United States out in the open to see if the U.S. would bite. Adding the extra perk of freeing hostages was sure to get the U.S. on board. This was enough to convince McFarlane to take the idea to the President. Reagan approved Israel to sell 100 American-made missiles to Iran, and in exchange they would release "some, if not all," of the American hostages (Chimene-Weiss, Eppel, Feigenbaum, Motel, \& Pangandoyon, n.d.). This first shipment took place in August of 1985, but no hostages were released due to a supposed "mix-up." But, if the U.S. would sell more missiles to Iran, surely the hostages would be freed. The second shipment of 408 missiles led to one American's release, much to the outrage of the United States who was promised more. Originally prompted by the promise of bettering relations with Iran, the United States continued this arrangement under the assumed hope of saving more hostages. However, this humanitarian mission soon faded as the primary motivator for the continued operations.

November's weapons shipment was the first to have its funds diverted to the Contras in Nicaragua. From here, the remainder of the arms sales were motivated by money. Selling weapons to raise money for the Contras became the major driving force behind the entire deal, whereas any hostages freed would simply be an added perk. This shows that the United States was not prompted to continue in the interest of saving lives. The "myth" of humanitarian motivations for the Iran half of the affair is indeed false.

The reality of the Iran deal placed Reagan in legal trouble because shipping weapons to Iran (even when facilitated by Israel) was prohibited under the Arms Export Control Act that barred weapons transfers to countries engaged in or supporting terrorism (Byrne, 2014). On 
December $7^{\text {th }}$, in wake of the presidential finding, Reagan held a meeting with advisors where he was warned of the legal troubles and violations that could potentially backfire. Reagan responded to these warnings by saying that the public would not understand if four hostages died because he "wouldn't break the law," and asserted "They can impeach me if they want” (Schultz, 1987, p. 32). These statements reflect a discursive effort to reinforce the "myth" that the arms deals were motivated by a desire to rescue hostages. Chief of Staff Regan believed the president wanted to keep the arms deals going because he feared looking inept as a President if the U.S. was unable to get hostages out, and this was his only chance at doing so (Tower Report, 1987, pp. B-52). However, Reagan was never held accountable for his directive action because according to McFarlane, Bill Casey suggested "that Congress should not be advised, and the President agreed with him" (McFarlane, Joint Hearings, 1987, p. 224).

After the December presidential finding, a newer draft was compiled in January that omitted any reference to hostages in the Middle East and instead focused on the goal of "establishing a more moderate government in Iran" (Draft presidential finding, 1986). Changing the syntax of the finding lessened its potential for creating political controversy should it be discovered, but it kept in place the earlier clause on barring those involved from briefing Congress (Byrne, 2014). This seemingly simple change in language was used as justification during the investigations that the Iran side of the operation was not an arms-for-hostages negotiation. Citing aspirations to create a more moderate Iranian government removed some of the personal responsibility that may have befallen Reagan during the Congressional inquiry into the affair. Reagan made it clear multiple times he wanted to get hostages out by any means necessary, but having this language removed from the finding minimized the likelihood of him being accused of making deals with terrorist organizations. The move was made not by himself, 
but by members of his administration acting in his best interest. This act is an example of how the Reagan faithful sheltered the President throughout the duration of the Iran-Contra Affair. Further evidence can be found in attempts to find the legal loopholes which Reagan could exploit should the shipments of arms to Iran ever be questioned.

Members of the administration found a combination of clauses from other pieces of legislation to get around restrictions to selling weapons to Iran. Based on a previous opinion given by an attorney general concerning a weapons shipment to Iraq in the early 1980s, the Economy Act allowed the Department of Defense to "sell" weapons to another agency (i.e. the CIA in this case), then through the National Security Act the President could approve a shipment of those arms to another party as a part of a "significant intelligence objective" (Smith, 1981). This same logic was applied to the Iran arms deals on the basis that the President has "inherent powers as Commander in Chief" and in the "ability to conduct foreign policy" (Weinberger, 1987, p. 142). After this reasoning was in place, the decision was made to continue holding off on notifying Congress until after hostages were released because of the perceived threat that a public announcement might hold for the arrangement with Iran (Byrne, 2014). However, the problem was that the hostage release part of the operation was always frustrating. With each arms sale, either no or too few hostages were released, but enough to be used by the arms traders to keep the U.S. government interested in continuing the operation.

The 1985-1986 Enterprise operations generated a large amount of surplus cash with which Oliver North created an "operational fund" account per instructions from Bill Casey while also maintaining "meticulous records," that he later destroyed at the request of Casey, supposedly to protect the identity of others involved (OIC Final Reports, pp. 193-197). 
Further into the Iran-Contra operation in May of 1986, Reagan expressed his frustration with Congress over Contra funding to Poindexter: "I am really serious. If we can't move the Contra package before June 9, I want to figure out a way to take action unilaterally to provide assistance" (Poindexter, Contra Project, 1986). Poindexter wrote that Reagan's resolute tone spurred a desire to move forward because he believed "The President is ready to confront Congress on the Constitutional question of who controls foreign policy" (Poindexter, Contra Project, 1986). Poindexter said he was prepared to anticipate Reagan's wishes, and acted accordingly (Byrne, 2014). Planning and acting preemptively on behalf of Reagan demonstrates the indirect influence he held over members of his administration that prompted them to act of their own accord to accomplish Reagan's goals. Byrne noted later in his book on the Iran-Contra affair that Reagan's staff possessed an eagerness to "jump into action whenever he expressed a strong policy preference" (2014, p. 229).

Summing up, the analysis so far shows how the Reagan administration was able to "secretly" fund a war in Nicaragua and "secretly" negotiate with Hezbollah the release of hostages. The production of secrecy required the personal commitment of the President and institutional coordination within the Executive Branch. Coordination of such a complex operation required a personal loyalty which President Reagan was particularly able to extract. President Reagan added the power of his personality to the power of the office to have his staff do what was needed without him even having to say it.

The analysis revealed that "saving Nicaragua from bloodthirsty guerillas" and "rescuing hostages" were not the driving forces of this whole operation. Rather, the U.S. wanted to maintain its own influence in Latin America by backing a rebel group attempting to overthrow the government. If the Contras were successful, the U.S. would have power in the region. 
Although rescuing hostages was a good way for Reagan to show he was not weak, the Iran arms deal became in the end the preferred channel for diverting more money to the Contras. Reagan and his administration saw the weapons deals as a means to circumvent Congress and provide monetary aid to the Contras while also maybe being able to free some of the hostages. The "myths" we have come to accept as the "obvious truths" of the affair are false. Instead, U.S. actions were motivated not by "national security," but by personal psychological and monetary needs. A president who fears appearing weak and arms dealers always searching for a market combined to design a secret scheme.

\section{Public Fallout}

The Lebanese news story and the shooting down of the plane carrying Contra supplies led to the cover-up stage of the affair. Numerous attempts were made to coordinate responses amongst the various agencies involved, but the result was a hectic and frenzied effort at protecting individual agency interests (Byrne, 2014). Some reactions were to protect the President, preserve the integrity of the administration, and to conserve the standing of the Republican Party with the upcoming 1988 presidential elections (Byrne, 2014). Damage control was in full effect, with each agency denying any connection to the downed Contra supply flight (North, 1991, p. 249). Congress was unwilling to make any direct accusation at the time, but nonetheless the desire for investigations into the affair pushed ahead.

When flak from the downed Contra supply plane subsided, press attention shifted to the Iran arms deal story. The White House, Departments of State and Defense, and the CIA all worked to curb their liability, with people like Poindexter insisting on making no public comment until officials had their stories straight (Byrne, 2014, p. 256). However, public pressure soon prompted a response, so Reagan met with advisors on November $10^{\text {th }}, 1986$ to compose a 
unified message. Reagan was apparently adamant in wanting to make a statement to the press as he was thoroughly convinced that his administration had "not dealt directly w/ terrorists, no bargaining, no ransom" (Regan, 1986). While no other officials present during this meeting shared the President's same conviction of innocence, no one openly opposed his statements. This is yet another example of the submissiveness of administration officials to Reagan's will. Even those with dissenting views were hesitant, or flat out refused, to voice their concerns.

Reagan's power had embedded a culture of silence not only in regards to keeping operations secret from Congress, but also in the sense that few would ever openly oppose the President's opinions and opted to remain silent rather than express opposition. Though they were privy to the 'knowledge' or information of what government was doing, they did not speak up and failed to fulfill their most basic function of discussing and critiquing policy.

Following the November $10^{\text {th }}$ meeting, Poindexter scrambled to find a timeline of events for Congress that would put the question of the legality of the Iran-Contra campaign to rest without incriminating the President (Byrne, 2014). He sought the counsel of McFarlane to help look over the narrative that had been assembled thus far. This exchange marked a significant event in the cover-up because McFarlane made multiple changes that were clearly intended to shield the President and his staff. One of these changes is the refutation that Reagan had never given approval for the initial weapons sales in the summer of 1985 (McFarlane, Chronology, 1986). Several officials hesitated upon seeing the new change, but when they were told it was added by McFarlane, those doubts disappeared and no one brought the subject up for debate (Byrne, 2014). Reagan held a press conference soon after, urging that they could no longer hold their silence in the media. It was an attempt to save some face by admitting to the diversionary scheme of selling arms and using the funds for the Contras though his speech contained several 
misstatements and mistakes that created more strife for the administration in the congressional investigation (Byrne, 2014). Some of the misstatements directly contradicted the narrative that the administration was trying to push with the public and with Congress to justify their actions and protect the President from legal fallout. A strategic advantage to holding this press conference though was that it gave the administration an aura of transparency. Rather than refusing to give a statement to the public, the president's willingness to come forward offered a minimum acceptable standard of transparency. This 'openness' was one of the first measures taken by the administration during the fallout to develop a positive image with the public, which would then hopefully influence the views of Congressional investigators.

The U.S. was trying to spin the narrative as one that kept the arrangement from looking solely like an arms-for-hostages deal, although Robert McFarlane (NSC advisor) admitted, "You would have to be a fool not to see that, whatever our intentions were, the reality was apparently arms for hostages” (Tower Report, 1987, pp. B-27). Conducting a purely arms-for-hostages negotiation was illegal, and therefore it was in the best interests of both the United States government's image abroad and domestically to find a more acceptable reason.

The November $24^{\text {th }}$ National Security Planning Group meeting resulted in Chief of Staff Regan advising Poindexter to be prepared to resign as national security advisor. The investigation was looking for someone to blame or else risk looking inept to the American public (Byrne, 2014). Poindexter, being the loyal servant he was, handed the President his resignation that same day. One official pled with Poindexter not to resign, urging him to finally "force the President to step up to the plate and take responsibility for his actions." Unfortunately, Poindexter already knew the truth and replied: "It's too late. They're building a wall around him" (Secord, 1992, pp. 330-331). 
Poindexter saw the reality that Reagan had become untouchable. His policy goals fostered a forceful allegiance amongst members of his administration. A desire to please the President led officials such as North and Poindexter to break laws, lie, and destroy evidence to safeguard Reagan from political and legal criticism. Poindexter was chosen to fall on his sword, and knowing that he himself had already crossed legal and ethical lines for the President, he knew the hopelessness involved in trying to ever hold Reagan accountable for inspiring the events of Iran-Contra. The initial public shock of the revelations of Iran-Contra subsided, and the Congressional committee investigations began to form and take place.

\section{Investigations}

Several committees were formed to handle the investigations in the Iran-Contra affair.

Many testimonies were heard, and many reports produced differing results, but little punishment was produced as a result. The almost hangover-like feeling from Watergate seemed to have removed a bulk of the teeth from the investigations into Iran-Contra. Multiple officials were called to testify, some under a condition of immunity, and the resulting reports failed to assign blame in such a way that held anyone accountable for their actions. The lackadaisical proceedings played a part in solidifying secrecy and a minimum standard of transparency. In this sense, the Iran-Contra Affair is a special event that helps understand how secrecy is the normal standard of American democracy and not an anomaly in an otherwise transparent political system. Democracy in the United State works because some things are kept secret. Many people believe that secrecy has, or should have, no space in democracy, yet this is a "myth."

During the investigation, McFarlane initially lied about his involvement, stating, "I did not solicit any country at any time to make contributions to the Contras" (McFarlane, Testimony before the U.S. House Foreign Affairs Committee, 1986, pp. 58, 66). The outright deception here 
by McFarlane may be blatant but reflects the actions of many others involved directly in the IranContra Affair. McFarlane later revealed in testimony that Reagan had sworn him to secrecy on the third-party donation because of the possibility of harming U.S.-Saudi relations or decreasing the likelihood of Congress renewing aid for the Contras (McFarlane, testimony at Oliver North trial, 1989, pp. 4201-4206). McFarlane is one of the few Reagan administration officials that blamed the President for influencing his actions and encouraging a culture of secrecy regarding the Iran-Contra operations. Though McFarlane was forthcoming with his information on the President's policy preferences, he still carried out the President's orders during the affair instead of reporting the actions to Congress. Obeying orders to remain silent is an example of the power Reagan held over officials in his administration. Reagan's goals and direct orders encouraged and demanded secrecy. There was no concern for overlooking legislative action or the administration's promises to not provide aid. The sole concern was what would happen to the Contras, and to Nicaragua/Central America if Congress discovered the ongoing operation (Byrne, 2014).

Robert McFarlane testified during the Congressional investigation that he never considered the NSC to be bound by the Boland II amendment (McFarlane, testimony at Oliver North trial, 1989, pp. 3975, 4138-4140). He believed the NSC to technically, according to its purpose, be outside of the agencies which fell under Boland. Further, there was debate whether the amendments included the President personally. One historian argued that while legally the President was not named, "he clearly could not act alone and would have had to act through governmental agencies specified directly or indirectly in the amendment" (Draper, 1991, p. 25). Reagan was able to establish a status quo of secrecy without having to directly state his intentions. This is yet another example of the power of the President, namely the influential 
power of Ronald Reagan's charismatic personality. Reagan is clearly one of the primary "authors" of the Iran-Contra Affair because his ideology, personality and institutional status placed him in a position to affect policy and shape the administration's culture.

Many believe that those involved were too impatient for results, perhaps because of presidential pressure, and this impatience led participants to cut too many corners (Byrne, 2014). Oliver North, as a key player in the affair, received heavy scrutiny in the Congressional investigation. Some claimed North had a profound tendency to fabricate information so long as it influenced events in his favor, yet this characteristic was glossed over by his superiors due to his commitment to carrying out the causes which both him and the President supported so passionately (Bradlee Jr., 1988, pp. 544-547). He tended to make sudden judgments for maximum short-term gain, completely disregarding any potential long-term consequences his actions may produce (Byrne, 2014, p. 249).

North admitted his penchant for lying when it came to getting results in the Iran-Contra operations, stating, "I would have promised them a trip to Disneyland" in his Congressional testimony (North, Joint Hearings, 1987, p. 8). In facilitating the connection between the Iran arms-for-hostages situation and the Contras rebels in Nicaragua, North's actions, interactions, comments, etc. are all important items of investigation in deciphering how/why secrecy, instead of transparency, was developed. His willingness to say whatever it took to achieve his goals is reflective of the actions of the rest of the administration. North is clearly yet another "author" of the affair, and was motivated by his eagerness to follow orders and please the President. North bought into the official version of the Iran-Contra narrative that the U.S. was conducting its operations to stop the spread of Soviet communism in Latin America, and to free hostages taken by Hezbollah because they valued American lives. A 'by-any-means-necessary' mentality is 
what helped to unofficially solidify a culture of secrecy, and during the investigations a minimum standard of transparency was put forth to placate Congress and the public.

Discoveries by Congress of early U.S. covert intervention in Nicaragua showed signs of the unwavering loyalty to the President that are present in much of the later Congressional fallout. Administration officials flat-out denied the involvement of President Reagan, stating that he did not authorize covert action (Byrne, 2014). This intense loyalty will come to be characteristic of many people inside the Reagan administration in the aftermath of Iran-Contra. It is important to note, however, that loyalty is not exclusive to the Reagan administration. This is an element that is present throughout many past and present-day administrations. The President, as the head of the executive branch, controls much of the foreign policy agenda and can exert a great deal of influence to accomplish his goals. What is significant about this case though, is the illegal activity that was revealed to the public, yet went unpunished. It made visible the mechanisms of power wielded by the president to infuse a culture of secrecy into the routine practices of administration officials, and showed the acceptability (whether intentional or not) of that secrecy by the American public.

Questions were raised about the extent of information to which Reagan was privy regarding North's NSC Contras operations. Poindexter, who replaced McFarlane as National Security Advisor, said of the President: "He knew the NSC staff was running support for the Contras. The only thing he didn't know was about the use of excess funds for the Contras (Poindexter, interview with the author, 2013). Reagan confirmed this point in his testimony at Poindexter's trial in 1990, where despite his failing memory, he gave a detailed understanding of North's actions (OIC Final Reports, p. 449). Though at the time, Poindexter claimed to have had the President's seal of approval, and justified the falsehood by urging the operation was the only 
way to help Reagan accomplish his goals (Byrne, 2014). Poindexter possessed an undying loyalty to the President, wholly believing in his objectives.

Ceaseless allegiance to Reagan still stands firm as a common theme that emerges from many of the testimonies given by those involved with the Iran-Contra Affair. Multiple statements reflect the President's wishes to continue with both the Iran and Contras operations based predominantly on his desire to rescue hostages and fight the communist influence in Nicaragua by funding the rebels. The ideological power and influence of Reagan is present throughout the testimonies of multiple administration officials. But there is a clear lack of evidence of any sort of cost/benefit analysis for pursuing these policies. No notes, memos, or testimony have any mention of the potential consequences for interfering in Nicaragua or giving arms to Iran. There seems to be a blatant disregard for the potential after-effects of waging a secret war in Latin America or for providing weapons to a state in the midst of a military conflict. Only selfcentered motives seem to have guided policy in the Iran-Contra Affair. Although a strong desire to achieve specific goals is characteristic of almost every president, the Iran-Contra Affair exemplifies an instance of the revelation of illegal activity, the lowest acceptable level of transparency to pacify Congress, and the people's acquiescence with those practices.

The original December $5^{\text {th }}$ finding created legal issues for the administration during the investigation because it was signed after arms trades had already been made, and therefore only the ensuing deals were covered under the finding (Byrne, 2014). The finding went against the White House narrative that the campaign was centered on developing a strategic relationship with Tehran. The "official" justification put forth by the Reagan administration shows an attempt to keep secret an arms-for-hostages agreement. This agreement allowed Israel to replenish its arsenal and allowed private arms traders to make millions of dollars in profits. In the end, the 
United States did not get all the hostages and it did not gain influence with the Iranian government. The costs of the arms arrangement were never discussed.

In other testimony, Secretary of State Shultz maintained he was ignorant of the later stages of the Iran weapons exchanges despite memos intercepted that stated otherwise. Prosecutors in the Congressional investigation concluded that Shultz's approach was to avoid giving "harsh private criticism of President Reagan" and other officials (Walsh, 1998, pp. 325326). So, although past notes revealed Shultz was critical of the weapons deals with Iran, he refused to openly condemn the President and the rest of the administration during the Congressional fallout. Even those not enamored with Reagan's policy goals were still willing to withhold information from Congress. This may have been more self-serving for Shultz, knowing that it would be political suicide to openly criticize the President, because doing so would mean revealing evidence that he had been in possession of since the early stages of the Iran-Contra operations, therefore incriminating himself in the process. Schultz's silence is evidence of a "culture of secrecy" that developed in the administration. His silence is an example of the effect of power exuded by Reagan and his administration.

Investigators pressed even further, probing for more evidence of illegal activity. Poindexter was asked to produce documents relevant to Iran-Contra, which led to him and Oliver North subsequently destroying several records that could potentially doom the administration. One of the documents destroyed was the first preliminary finding signed by Reagan in December of 1985 (Byrne, 2014). Poindexter believed the finding would make the operations look strictly like an arms-for-hostages negotiation and he had "decided that it would be politically embarrassing to the President at this point because it would substantiate what was being alleged..." so he "decided to destroy it" (Poindexter, Select Committees' deposition, pp. 1109- 
1110). North and his secretary also aided in the shredding of documents that would have been rather incriminating for himself, the President, and the entire administration. This blatant obstruction of justice went unpunished. There were no consequences, no convictions, no followups. Poindexter admitted to destroying evidence for Reagan's benefit. He wanted to protect the President, and the above quote demonstrates his high degree of loyalty.

The shredding of documents is a concrete example of the cover-up efforts that went into motion to begin erasing the affair from history. If there was a lack of physical evidence, the administration believed the affair would fade from public consciousness soon after its exposure. Here, we have another piece in the culture of secrecy created by the "authors" of the Iran-Contra Affair. The destruction of evidence contradicts the "official version" of the justifications for secrecy: fighting communist expansion and saving the lives of hostages. How did shredding these documents benefit those stated reasons for secrecy? North's and Poindexter's exploits in the face of Congressional inquiry suggest an ulterior motive. This stage in the investigation appears to have poked holes in the administration's alibi.

Poindexter's testimony offered more reflection upon the intense loyalty possessed by Reagan administration members. He worked with the President for many years, and claimed he "was convinced" that he "understood the President's thinking on this." Regarding Nicaragua, he said, "the policy was very clear, and that was to support the Contras." Therefore, the operations were a means to implement this policy (Poindexter, Joint Hearings, 1987, pp. 36-37, 40). Poindexter believed, "I was convinced that... if I had taken it to him that he would have approved it." By not taking the specifics on the implementation of policy to the President, he knew it would "provide some future deniability for the president if it ever leaked out" (Poindexter, Joint Hearings, 1987, pp. 37-38). Not going to Reagan for authorization was a 
means to shield him from legal scrutiny should the affair ever leak, yet it was still a means to continue to carry out the President's policy goals. The testimony given by Poindexter showed him to be much more loyal to the President than North, yet he was less credible to investigators because they found it hard to believe that his spotless reports in the Naval Academy would suddenly become sloppy while working in the Reagan administration (Byrne, 2014, p. 299). Investigators that examined the numerous testimonies concluded, "There is a tremendous amount of circumstantial evidence that Reagan knew, but there is no direct evidence" (Article in Periodical, 1987). The committees were exhausted after the number of hours spent hearing testimony and deliberating amongst themselves, and soon after, the hearings began to subside. The historical context contributed to the ease with which Congress tired of the investigation: the Watergate scandal of the 1970's still hung over their heads and they did not wish to put the American people through another impeachment. The popularity of Reagan alone would have made that a daunting task, but the Republican Party could not stand to suffer another such blow.

The lack of penalty imposed on Poindexter can be traced back to Edward Meese, Attorney General in the Reagan administration. Meese did not see himself as the chief law enforcement officer in the United States, but instead saw himself as the President's "most trusted political confidant" (Byrne, 2014, p. 274). In the investigation, Meese claimed to find little evidence of breaking the law. Rather than pressing for evidence, his subordinates believed his goal was to shield the President and his administration (Byrne, 2014). The widespread commitment to Reagan during the fallout from the scandal reflects an obvious disregard for due process, but shows that the President was able to sway officials within his administration to wholeheartedly dedicate themselves to his goals. The production of secrecy was not only present throughout the Iran-Contra campaign, but also in the investigations process. A culture of silence 
was produced amidst all who were loyal to the President. In this part of the case, it is clear that the costs of prosecution were weighed, but the "benefits," such as due process, or not letting instances of executive abuse go unpunished, were not. Party self-interest and loyalty came before the law.

When McFarlane testified before the various committees running the investigations, he was one of the few that did not sacrifice himself to shield Reagan. His testimony illuminated the President's role in the affair, primarily his approval of the deals, and confirmed that the President wanted to take advantage of developing a strategic long-term relationship with Iran by gaining the short-term goal of freeing hostages (Byrne, 2014, p. 291). McFarlane's testimony directly contradicted statements made by North and other officials that they had all acted legally. Even when North was confronted further about the legality of his actions, he had no intention of falling on his sword. He passed the buck on to his superiors, claiming he always had clearance to proceed, even after Poindexter no longer deemed it necessary to ask Reagan for approval. North justified his actions by saying that serving the wishes of the President took precedence over honesty to Congress (Byrne, 2014, p. 297).

These final statements in the investigations yet again reflect the mismatch between the “official narrative," or justifications for secrecy, and the reality of what happened. McFarlane was one of the few which openly disputed the official version of the Iran-Contra Affair where the purpose was supposedly to rescue hostages and fight off communism in Latin America. A critical analysis of the affair has shown that the justifications for secrecy do not coincide with the actions, or true motivations, of the "authors." Secrecy was produced illegally during the operations, and for the purpose of covering up the affair. Officials were able to put forth a front of being transparent with Congress, and this false transparency seemed to satisfy the people in a 
way that caused them to shrug off the affair as if nothing had happened, and the memory began to fade.

\section{Investigations Come to a Close}

The Iran-Contra scandal was on the heels of Watergate during the Nixon administration, yet this affair emitted a different tone. Before the Congressional investigation into Watergate, many already believed Nixon had engaged in criminal activity and found him guilty and worthy of impeachment. Conversely, Reagan was beloved not only by those in his administration, but also by the American people. In the summer of 1987, the U.S. public saw Reagan's role as comprising questionable policy choices, or lack of control over the actions of his administration, rather than him taking part in illegal exploits (Byrne, 2014, p. 279). Not only did the actions of Reagan's loyal help preserve his place in office, but the political climate and his popularity with the American public also aided his defense. The public sphere was stunted in its ability to hold the executive accountable because of their confusion and blindness to the reality of the affair. The administration was able to give just enough information to placate Congress and the people, even though their justifications did not match up with the results. There was a lack of critical analysis in the investigations because of the unwillingness of Congress to subject the United States to another public scandal and potential embarrassment to the Republican Party.

Reports produced following investigations into Iran-Contra cited a "flawed process" or a "failure of responsibility" on the part of multiple top level officials, whereas Reagan was accused of not seeming aware of the actions of his aides (Tower Report, 1987, pp. IV-11). Rather than claiming Reagan was the source of the problem, reports were more critical of his management style and seeming lack of oversight. Criticizing Reagan's management style portrayed him as more of a victim as opposed to the driving force behind the affair. Later evidence would show 
his more active role, but others identified a significant contributing factor in Iran-Contra: Reagan's distaste for elementary policy details (Byrne, 2014). An investigator said that his impression of the President was that "he had a few big principles and he pushed hard on those, but he wasn't that interested in managing," and that his implied approval for the Iran-Contra operations was enough for his aides to take on the responsibility of the campaign themselves (Byrne, 2014, p. 286).

The committees had more criticism for Reagan's staff rather than for the President himself, even though there was direct evidence that Reagan had been prepared to circumvent the law to obtain the release of hostages (Byrne, 2014). Despite the evidence, the committees chose to dismiss Reagan's actions. This decision is assumed to have been made in what Congress saw as the best national interest and to preserve the political party. Although some concluded that Reagan "had created the conditions which made possible the crimes committed by others," they believed that Reagan's actions ultimately "fell well short of criminality which could be successfully prosecuted" because "it could not be proved beyond a reasonable doubt that President Reagan knew of the underlying facts of Iran/Contra that were criminal or that he made criminal misrepresentations regarding them" (OIC Final Reports, p. 445). Poindexter noted that Reagan "knew the job was getting done. The exact way we were getting it done was something that would not have been particularly relevant to him" (Poindexter, Select Committees' deposition, p. 1311). The culture of secrecy created in the Reagan administration offered a shield of plausible deniability for the President during the investigations. Reagan's ideology and personality created power, which translated through his broad policy goals, produced this culture. The means through which secrecy was produced fall well short of the stated motivations 
of the "authors" of the affair. If stopping communism and freeing hostages were the goals, why was there such a concerted effort to shield the President?

Despite the impunity towards the President, Oliver North was found guilty on three counts: preparing a false chronology and altering/destroying documents; removing, falsifying and destroying document on covert programs; and accepting illegal gratuity (Byrne, 2014, p. 315). However, the charges were vacated shortly after because his testimony may have been tainted though there was no concrete evidence as such. He had testified under a limited condition of immunity, which would become his saving grace in the vacating of his sentence. Letting North walk free is another example of the "culture of secrecy" produced out of the Iran-Contra Affair. North disappeared from the public eye, and this contributed to the forgetfulness of the public. With no public figure being punished for the affair, there was no one in the news left to talk about. There was no discussion taking place in the public sphere because according to the "elite," there were no actual crimes to discuss.

One of the important factors that arose from the investigations was President Reagan's state of mind both during and after the affair. In an interview that look place years later, Poindexter said he believed that "by the end of $1986 \ldots$ Alzheimer's had really begun to be a factor" for Reagan, but he was also impressed with the President's ability to hide his thoughts and mood from others (Poindexter, 2013). Could this have been a contributing factor in Congress' seeming unwillingness to prosecute Reagan?

The final report on Iran-Contra depicted a profoundly critical narrative: "The common ingredients of the Iran and Contra policies were secrecy, deception, and disdain for the law" and that those involved believed "they alone knew what was right." "A small group of senior officials took part in 'pervasive dishonesty' and undermined the balance Congress is meant to 
provide against the Executive" (Select Committee, undated). These statements reflect the elite making decisions without the public sphere's critique. Secrecy was produced to help illegally achieve policy goals, then the elite were able to flood the public debate with their own discussions and guises of "transparency" to induce forgetfulness in the public sphere.

Choosing to not press further on Reagan undermined the bearing of the investigations and soon enough the original sting of the Iran-Contra affair started to fade out from public view as attention shifted to the 1988 presidential elections. The Iran-Contra affair was finally laid to rest on Christmas Eve of 1992 when President Bush issued pardons to several actors in the affair (Byrne, 2014, p. 325). As stated before, this act was the cherry-on-top for the culture of secrecy created by the Reagan administration. President Bush had been a part of that culture while serving as Reagan's Vice President, and it was therefore also in his best interests (primarily for the future of his tenure in office) to officially lay the affair to rest.

In defense of his pardons, Bush stated:

"The common denominator of their motivation- whether their actions were right or wrong- was patriotism." He criticized the drawn-out investigations run by Walsh as reflective of "what I believe is a profoundly troubling development in the political and legal climate of our country: the criminalization of policy differences" (Chimene-Weiss, Eppel, Feigenbaum, Motel, \& Pangandoyon, n.d.).

Walsh, the special prosecutor appointed to the Iran-Contra Affair case, responded to Bush, saying:

"The pardon of Caspar Weinberger and other Iran-Contra defendants undermines the principle that no man is above the law. It demonstrated that powerful people with powerful allies can commit serious crimes in high office- deliberately abusing the public trust without consequence.... The Iran-Contra cover-up, which has continued for more than six years, has now been completed with the pardon of Caspar Weinberger." (Chimene-Weiss, Eppel, Feigenbaum, Motel, \& Pangandoyon, n.d.)

Some key elements of these comments should be pointed out. Bush invoked "patriotism" in his remarks, which is undoubtedly a mechanism of power that has been used by many Presidents. 
Instead, he blames Congress for the Iran-Contra scandal. He reduced the events of the affair to mere "policy differences" which is a tactic to downplay their significance. It was Bush's way of saying “it was no big deal.” Bush's statements, along with his pardons, were exercises of power that were meant to induce forgetfulness into the public by invoking "patriotism" borne out of a desire to protect national security, which has already been shown to have been a false motive in the affair.

Walsh counters Bush's remarks by saying that there was no due process. He is one of the few voices in this investigative process that asks why no one else seems to see how significant the entire affair was. Walsh realized the implications of Bush's pardon, and tried to urge the public to not let the elite win. He echoes what this thesis has been saying: "why does no one care about this?" "How did no one get in trouble?" "People, do not forget about this affair!"

The Iran-Contra Affair was indeed an extreme circumstance of the productiveness of presidential power and its capability to create a culture of secrecy that spreads throughout an entire administration. Once the extent of the secrecy was revealed to the public, the administration's damage control encouraged a minimum standard of transparency to avoid blatantly lying to Congress, but to say just enough to placate investigators.

The impunity of the situation along with the pardon issued by President Bush essentially closed the door on Iran-Contra, and the entire affair receded from the front of the public mind. The story of Iran-Contra follows the evolutionary journey of power; beginning with the production of secrecy from the position of power (the President, administration officials), to the maintenance of a modicum of transparency in the investigations, and ending with an illustration of the erosion of the public sphere. The public never expressed strong points of view on the affair, meaning that the purpose of the public sphere was never realized. As stated before, the 
purpose of the public sphere is to discuss the policies and activities of government. Even after the events of Iran-Contra were made known to the public through the media, the multitude of investigations and committees created confusion where the public was unable to find a focal point for critique. Investigational proceedings were scattered so thin that the public could not hone in on the details, leaving them unable to properly judge their actions.

The authors of the affair produced a culture of secrecy under the official narrative of freeing hostages and fighting communism. The benefits calculated into the decision were the profits of arms traders and the satisfaction U.S. policymakers had in displaying power over a weaker state like Nicaragua. The costs in terms of effects on U.S. democracy and the lives of people in Nicaragua and Iran were discounted.

The process through which secrecy was produced shows a flagrant disregard for the consequences of the administration's policies. Not once during the investigations are the consequences of the secret war in Nicaragua discussed, nor the destruction and death caused by supplying weapons to both sides in the brutal war between Iran and Iraq. The interference of elites in the public sphere inhibited its ability to properly discuss and analyze the actions of the executive. Controlling knowledge through secrecy and the control of information is an exercise of power. Secrecy emerged as the status quo for the Reagan administration in the Iran-Contra Affair to protect personal and economic interests. Fighting communism and rescuing hostages were justifications. 


\section{CHAPTER VI: CONCLUSIONS}

The Iran-Contra Affair offers a case of crimes gone unpunished. The mechanisms of secrecy and transparency that developed demonstrate the productive capabilities of power. Power can produce a great many things, and its relationship to knowledge is inseparable. The "authors" of the Iran-Contra Affair had the power to produce a culture of secrecy within the Reagan administration to aid in the cover-up of the operations. During the investigative stage of the affair, the "actors" produced the minimum acceptable standard of transparency to satisfy both Congress and the people of the United States that the acts committed by the administration were rather insignificant in the grand scheme of things. Or, as Bush believed, they were mere "policy differences."

Secrecy had planted its roots in U.S politics and the federal government well before the events of Iran-Contra took place, yet its acceptance and widespread use since the end of World War II helped set the stage for the events that followed. President Reagan and his administration believed in the power of the executive office. This belief was at the core of many policy decisions/opinions held by the President.

When Reagan took office in 1981, the current relationship between the executive and legislative branches was already strained, and there was a tense global environment created by the Cold War with the Soviet Union (Byrne, 2014). Congress was still reeling over the fallout from Watergate, and the Republican party was trying to get back on its feet after suffering that major blow. The international political climate during this period was a driving force behind Reagan's motivations to put an end to the Sandinista regime in Nicaragua. He believed that if Nicaragua fell into communist hands, it would be but a stepping stone for the rest of Latin 
America to fall under Soviet influence. This assumption has remained unexamined over time, but is ultimately deemed a "myth," that is, an ideological cover-up for other true motivations.

The Iran half of the affair comprised of the exchange of weapons for hostages, supposedly motivated by the humanitarian mission of saving American lives. However, this official version is also found to be a "myth." The shredding of evidence during the affair would not have been necessary had the motivations of the administration truly been for humanitarian reasons. The arms deals continued out of the need to obtain funds by whatever means necessary for the Contras. Myths are ideological tools for hiding true motivations.

While a discourse was designed to reaffirm "obvious truths," a hermeneutical analysis showed them to be "myths," that is, accepting things that are not true. Reports produced at the conclusion of the investigations cleared Ronald Reagan of any guilt, stating instead that he was just a "victim of poor management". President Reagan was shown, however, to have been a driving force behind the affair. His strong personality and ideology were able to persuade administration officials to take on a by-any-means-necessary mentality to achieve his policy goals. Officials were willing to fall on their sword to shield the President from any legal responsibility, and the culture of secrecy was able to wipe Reagan's culpability from both the minds of Congress and the people. The "President was not responsible" is a myth. People believe it, although it is not true. President Reagan was shown to have been a primary motivator behind the affair, with his fear of appearing weak as motivation for pushing for arms deals and communist rollback. However, "fighting communist influence in Latin America in the name of national security" was also a "myth," a mere justification to avoid legal prosecution for actions in Nicaragua. President Bush writing-off crimes as "patriotism" is an example of this justification and it is an excuse that seems to have become accepted in American society as a worthy reason 
to break the law, regardless of whatever consequences may have been produced. Anything is acceptable if done "in the name of the nation."

On the other side of the affair, the supposed motivation of rescuing hostages is yet another "myth" that emerges from an analysis of Iran-Contra. Instead, I found that the individuals involved in the inception and maintenance of the Iran arms deals were driven by their own personal desires for money and prestige. Selling weapons to raise money for the Contras became the crux of the operation. On Reagan's end, his fear of looking inept and weak to the American public led him to employ discursive efforts to reinforce the "myth" of humanitarian motivations for the Iran arms deals. In this sense, "myths" are ideological tools to cover up true motivations.

Another "myth" debunked in the analysis is the notion of democracy's inherent transparency. This façade should be replaced with democracies putting forth a minimum level of transparency that is enough to placate the people. We are aware that the government lies and keep secrets. We know we are not told everything, yet we still believe in the idea that our democracy here in the United States is transparent. Government secrecy and true government transparency do not mesh. Democracy in the U.S. works because there are some things which are kept secret; the average citizen has at least some knowledge of this inherent fact. However, many people still seem to believe that secrecy is a cancer to, impossible in, or nonexistent in a democracy. We cannot be aware of, or satisfied with secrecy and still truly believe the government is being transparent with its citizens. Clearly, we believe in the appearance, or reputation, of transparency, not in its reality. Government secrecy has been shown to have become "common sense" in democratic society. So, how low can transparency go? Enough to pacify the public. 
While the Iran-Contra story is but one example of the capability of power to produce secrecy and to cover up true motivations with "myths", this same logic is found in other cases. For instance, the Edward Snowden leaks that took place in 2013 also reveal how power creates a culture of secrecy. Snowden, a former contract analyst for the National Security Agency (NSA) disclosed thousands of classified documents that depicted the NSA's ability to spy at will not only on foreigners, but also on U.S. citizens through the collection of phone call data, internet searches, and other online activity. These programs were publicly justified in the name of national security to help the U.S. get more information on potential terrorist plots. But Snowden also believed the government was motivated by personal psychological needs and monetary greed, similar to the conclusions found from the hermeneutical analysis of the Iran-Contra Affair.

Snowden's revelations were received with mixed reactions: on the one hand, many considered him a hero for sparking widespread debate on mass surveillance and government secrecy, on the other hand, he is considered a traitor for disclosing national security secrets. While his story continues, it brings to light the same basic idea that was brought forth in this thesis: government keeping things secret for the wrong reasons, that is, to cover up other true motivations.

The government's successful production of secrecy gives it more power. The control of information and knowledge as a secret is an exercise of power. Those in power want to remain in power. Giving knowledge to the public and allowing the public sphere to influence policy means less power for policymakers. If the public sphere expresses strong opinions on foreign policy, the President and his administration are not able to push their agenda as effectively. If the people do not know about the policy at all, then instances like Iran-Contra can take place. The Iran-Contra 
Affair was not completely absent in the public sphere. It was part of the news and the media brought it into the global spotlight. However, power showed its productive capabilities again in the investigations by stunting the ability of the public sphere to critique the policies of the executive. The culture of silence was deployed to offer the front of transparency without giving up any information at all to investigators. It was enough to satisfy the people, and eventually, it phased out of public discussion.

The fading of Iran-Contra from public memory demonstrates a certain level of acceptability of secrecy in democracies. As stated at the beginning of this thesis, not all secrecy is bad. Not all secrecy yields negative results. An example of secrecy producing positive effects is seen in the U.S. operation to find and kill Osama bin Laden in 2011. The United States government refused to communicate its intelligence or intentions with the Pakistani government, and the operation, details, planning, etc. were not made public until well after the mission took place. Keeping information secret in this case paid off. But, as is shown by the hermeneutical analysis of the Iran-Contra Affair, this is not always the case. The executive must maintain a balance between an acceptable standard of secrecy and the potential abuse of power that can result if secrecy is justified for deplorable reasons.

The secrecy produced by Ronald Reagan's power yielded illegal and harmful results. The way in which secrecy was produced in the Iran-Contra Affair makes it unacceptable. While the outcome of this case is unique, Reagan's actions are reflective of the power contained within the office of the Chief Executive. Each U.S. President has had the power and capability to produce secrecy, sometimes justified in the name of national security. But the justification of secrecy in Iran-Contra to save lives and fight communism has been shown to be a "myth." I found instead that U.S. actions were caused by personal psychological and economic motivations: a president's 
desire to avoid appearing weak and arms dealers wanting to make money, without consideration for the consequences of their actions.

Years after the affair, a comment on the attitude held by those in the Reagan White House said, "I learned that people in the White House will do anything to protect the President. It is the mantra. It is the reason for their being there: protect the president at all costs. Fall on your sword.... That was very apparent with Poindexter and North, but it's true with any aide to the president at any time" (Hamilton, 2013). This quote displays what has been conveyed clearly throughout this thesis- the intense loyalty administration officials had for Ronald Reagan. But it also shows the applicability of this loyalty to any presidential administration.

Surely, President Reagan was not the only president to have officials break the law to achieve policy goals. It can be applied to many other administrations, Iran-Contra is just a welldocumented, public example. We may not know of the other instances in which this occurs because the culture of secrecy may be thorough and successful. The outcomes of each culture are not always the same. Sometimes it ends like Watergate with the impeachment of a President. Other times it ends with no one being held liable for criminal activity. And much of the time, most actions are never made public.

An integral aspect of the relationship between government and the public sphere is the means through which secrecy and transparency are produced. The current political climate in 2017 has already hinted at the possibility of a culture of secrecy forming in the Trump administration. The media constantly reports on possible interference in the 2016 elections, potential administration ties to Russia, and accidentally spilling national security secrets. We are in a time where secrecy seems to have become more relevant than ever before. We can use the events of Iran-Contra to critique today's political arena. A lesson to be learned from Iran-Contra 
is the ability of secrecy to tranquilize the public sphere to the degree that it cannot exercise public opinion on government. We should take the outcomes of Iran-Contra as a warning, and be careful to not fall asleep at the wheel. The public sphere possesses great potential power, and in situations like the ones we find ourselves in today, it is important to not let that power be taken away from us.

Future research should consider delving more thoroughly into additional cases of government secrecy, such as the Edward Snowden leaks, to see if this trend of government "myths" and "obvious truths" also hold true in other instances. The vast resources available on the Iran-Contra case makes it easy for the average researcher to get lost in the material. The abundance of information gives the impression of trying to drown the researcher to prevent them from reaching their goals. While it may not be a popular or conventional topic, subjecting the Iran-Contra Affair to a hermeneutical analysis has proven a worthwhile endeavor. It has shown the smokescreen that has been placed over the eyes of the public and revealed the true motivations of the "authors" which wished to have the affair erased from public consciousness. The "authors" of the Iran-Contra Affair produced a culture of secrecy under the narrative of fighting communism and rescuing hostages. Simultaneously, the effect these actions would have on U.S. democracy, and the effects felt by the people of Iran and Nicaragua, were discounted. Through the debunking of the Iran-Contra "myths," I have come to the conclusion that we live in a society where power can produce a culture of secrecy that can induce forgetfulness in the public sphere. While power is deployed to keep things secret, it is also deployed to make people forget. But it takes even more powerful voices to articulate this effect of power to the public. We must not forget. In cases where punishment is not adequate to the crimes committed, sometimes the best thing we can do is to keep memory alive. 


\section{REFERENCES}

Article in Periodical. (1987, July 28). Globe and Mail.

Biography.com Editors. (2016, October 13). Oliver North Biography. Retrieved from

Biography.com: http://www.biography.com/people/oliver-north-9425102

Bradlee Jr., B. (1988). Guts and Glory: The Rise and Fall of Oliver North. New York: Donald I. Fine.

Byrne, M. (2014). Iran-Contra: Reagan's Scandal and the Unchecked Abuse of Presidential Power. Kansas: University Press of Kansas.

Chimene-Weiss, S., Eppel, S., Feigenbaum, J., Motel, S., \& Pangandoyon, I. (n.d.). (T. C. University, Producer) Retrieved 2017, from Understanding the Iran-Contra Affairs: https://www.brown.edu/Research/Understanding_the_Iran_Contra_Affair/index.php

Diamond, J. (2008). The CIA and the Culture of Failure. Stanford: Stanford University Press.

Draft presidential finding. (1986, January 3). Iran.

Draper, T. (1991). A Very Thin Line: The Iran-Contra Affairs. Hill and Wang.

Emerson, S. (1988). Secret Warriors: Inside the Covert Military Operations of the Reagan Era. Putnam.

Finding Pursuant to Section 662, Scope: Hostage Rescue--Middle East. (n.d.).

McFarlane, R. (1986, November 18). Chronology. 23:06.

McFarlane, R. (1986, December 8). Testimony before the U.S. House Foreign Affairs Committee.

McFarlane, R. (1987, July 14). Joint Hearings. 100-7(Part II).

McFarlane, R. (1989, March 10). testimony at Oliver North trial.

McFarlane, R., \& Smardz, Z. (1994). Special Trust. Cadell \& Davies. 
Minutes of National Security Planning Group meeting. (1985, Jan 18). Response to Threat to Lebanon Hostages.

National Security Planning Group Meeting-- Subject: Central America. (1984, June 25). Situation Room.

North, O. (1987, July 7). Joint Hearings. 100-7.

North, O. (1991). Under Fire: An American Story. 21st Century Press.

OIC Final Reports. (n.d.). 1.

Poindexter, J. (1986, May 2). Contra Project. 23:01:50.

Poindexter, J. (1987, July 15). Joint Hearings. 100-8.

Poindexter, J. (2013, January 14). interview with the author.

Poindexter, J. (n.d.). Select Committees' deposition. B-20.

Reagan, R. (1990). An American Life. Simon and Schuster.

Regan, D. (1986, November 10). notes.

Richelson, J. T. (2016). The US Intelligence Community (Seventh ed.). Boulder: Westview Press.

Schultz, G. (1987, July 23). Joint Hearings. 100-9.

Secord, R. (1992). Honored and Betrayed. Wiley.

Select Committee. (undated). Select Committees' Report.

Smith, W. F. (1981, October 5). CIA Exchange of U.S. Weaponry for (Deleted).

(1987). Tower Report. Bantam.

U.S. Department of Defense. (1983, July 13). Background.

U.S. National Security Council minutes. (1981, Nov 10). Strategy toward Cuba and Central America. Reagan Files website. Retrieved from http://jasonebin.com/nsc24.html

Walsh, L. E. (1998). Firewall. W. W. Norton \& Company. 
Weinberger, C. (1987, July 31). Joint Hearings. 100-10. 